Portland State University

PDXScholar

\title{
Waitperson/customer interaction as an example of community
}

Patricia Louise MacAodha

Portland State University

Follow this and additional works at: https://pdxscholar.library.pdx.edu/open_access_etds

Part of the Social and Cultural Anthropology Commons Let us know how access to this document benefits you.

\section{Recommended Citation}

MacAodha, Patricia Louise, "Waitperson/customer interaction as an example of community" (1991). Dissertations and Theses. Paper 4330.

https://doi.org/10.15760/etd.6214

This Thesis is brought to you for free and open access. It has been accepted for inclusion in Dissertations and Theses by an authorized administrator of PDXScholar. Please contact us if we can make this document more accessible: pdxscholar@pdx.edu. 
AN ABSTRACT OF THE THESIS OF Patricia Louise MacAodha for the Master of Arts in Anthropology presented November 6, 1991.

Title: Waitperson/Customer Interaction as an Example of Community.

APPROVED BY THE MEMBERS OF THE THESIS COMMITTEE:

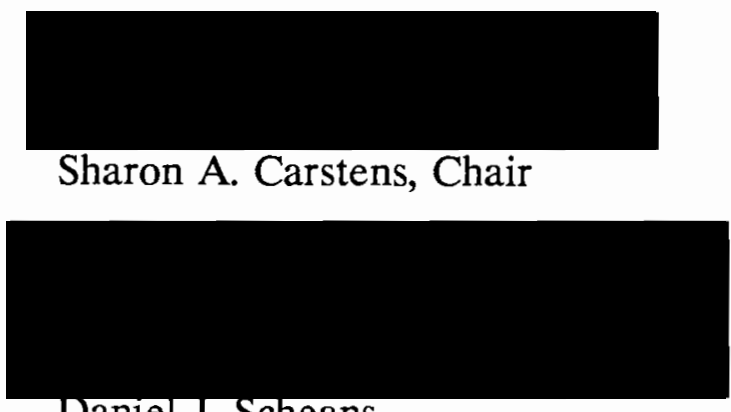

Daniel J. Scheans

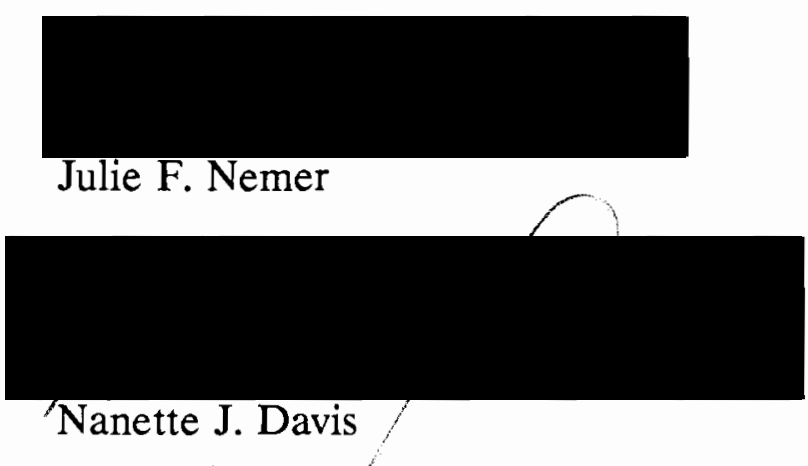

This thesis draws from research done in a particular urban setting, and illustrates the foundations of a type of social structure called "respite community". "Respite community" is a specifically urban phenomenon which can be defined as temporal, ad hoc, face to face, an aggregate of people who seek temporary relief 
from social stresses and support through socialized interaction.

The model proposed for identifying the "respite community" includes, at minimum, the following seven components:

1. There is an aggregate of people who have in common at least one consistent meeting place where they gather on a regular (frequently daily) basis, and where they become acquaintances, then familiars, then participants in an on-going group.

2. All members of this on-going group get something from regularly coming together in this location and context that emotionally sustains and nourishes them.

3. Each member is free, while participating in the group, to maintain her/his individual identity.

4. There is a consistent though flexible number of regular participants, a constancy of interaction among them, and a lasting element of involvement of the participants with one another (Henry 1958).

5. Participation in this "respite community" is voluntary, with no coercion toward, or on the part of, any involved individuals.

6. Individual members of a group may choose not to interact with other group members outside the specific location, even though participation in the group is important to each of them.

7. Certain behaviors are practiced, while others are not, based on the formal or informal consensus of the "respite community". The "rules" that govern group behavior are specific to behavioral understandings known only to the group.

A "respite community" can form in any informal setting where the seven elements 
described in the model above are found, whether at a community center flower arranging club or a chapter meeting of the Society for Creative Anachronisms. However, the data on which this thesis is based was mainly drawn from a cultural scene set in food service establishments, and focusing on interactions between waitpeople and their regular customers. The scenes included one restaurant, one cafe and one bakery/deli in Portland, Oregon U.S.A.

Four waitpeople, two waitresses and two waiters, were interviewed about their perceptions regarding their work, their work environment and their interactions with the regular customers they serve from day to day. These interviews were supplemented by over eighty-five hours of observations of waitperson/customer interactions in the establishments described above.

A literature review examines the concept of "community" as it has been perceived and its study developed in anthropology and in the sociological Chicago School theoretical analysis of urban culture. Urban social organization is discussed, including such contributing elements as ethnicity, migration of rural populations to the city, joking relationships in the workplace, gender issues and previously developed ethnographic research models which were applied in urban settings. Previous research on waitresses and waiters was also discussed as part of the existing literature on this subject.

Especially significant to the collection and analysis of data for this thesis was application of the "cultural scene" concept as developed by James P. Spradley. Methodology used to generate data for this thesis took many cues from the "cultural 
scene" in an urban bar, as described by Spradley and Mann (1975). The concepts of "real regulars" and the "Brady's Family" presented in this ethnography of cocktail waitresses provided foundations for the family concept that appears in my thesis, and which is basic to the "respite community".

In summary, this thesis shows that, although the word "community" is traditionally associated with a wholistic geographical location, complete with separate buildings and intergenerational and formal organization, the sense of community does not require that people live near each other, or have ethnic or kinship roots in common in order to feel a sense of community identity with one another. Many possibilities for "community" may exist in a world of complex social organization. The urban "respite community" is one of these possibilities. 


\title{
WAITPERSON/CUSTOMER INTERACTION
}

\section{AS AN EXAMPLE OF COMMUNITY}

\author{
by \\ PATRICIA LOUISE MacAODHA
}

A thesis submitted in partial fulfillment of the requirements for the degree of

\section{MASTER OF ARTS}

in

ANTHROPOLOGY

Portland State University

1992 


\section{TO THE OFFICE OF GRADUATE STUDIES:}

The members of the Committee approve the thesis of Patricia Louise MacAodha presented November 6, 1991.

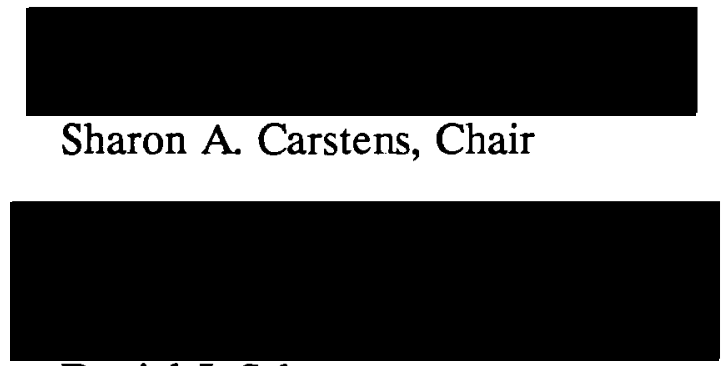

Daniel J. Scheans

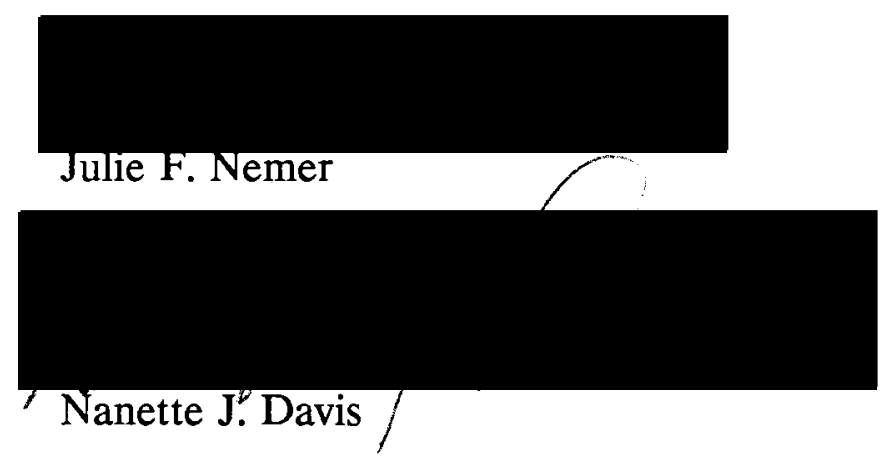

\section{APPROVED:}

Marc R. Feldesman, Chair, Department of Anthropology

C. William Savery, Interim Vice Provost foff Graduate Studies and Research 


\section{ACKNOWLEDGEMENTS}

No Master's thesis is written in a vacuum. The student needs people who give her/him technical assistance as well as emotional support. We learn who our friends are in this process that bears much resemblance to the training of a shaman in its intensity and challenge to the individual's sense of identity and self-esteem. The graduate student who emerges with thesis in hand is not the same person who began the process. If we are wise, we remember to thank the people who stayed up with us, gave us time they didn't have, had patience with us when we weren't seeing what we needed to see, and, most of all, who never gave up on us.

The names that follow belong to the people who performed these functions for me. Medals of valor are not given for the work they performed and the support they offered. It's a pity! Going through the thesis process often resembles being placed on a battleground.

I begin with the members of my Thesis Committee, my Advisor, Dr. Sharon A. Carstens, Dr. Daniel J. Scheans, Dr. Julie F. Nemer, all three of the Department of Anthropology, and Dr. Nanette Davis, of the Department of Sociology, all of Portland State University. Absent in life but not in spirit is the late Dr. Daniel T. Hughes, for many years Chair of the Department of Anthropology at The Ohio State University. His enthusiasm as a scholar inspired my own, and his help and support 
were vital at a critical time. The other faculty members in that department whose efforts in my behalf have been appreciated are Dr. John Messenger and Dr. Ojo Arewa.

I owe a great debt of gratitude to Connie Cash, the Departmental Secretary in the Anthropology Department at Portland State. Everything useful I have learned about computers and word-processing are to her credit (all the stupidities are mine, alone), and she has often been encouraging and supportive at times when I was ready to give up. At those times, a kind word and an expression of faith in one mean so much.

Likewise, I am grateful to the four people whose openness and willingness to share important details of their work lives in the restaurant industry made this thesis possible. Thank you, Marsha, Tad, Jerry and Oh Miss.

Finally, my thanks goes to members of my family, who couldn't escape, but who have been with me in this process, and without whose incredible tolerance and understanding I would never have gotten this far. I am especially grateful to my children, Haunani Chang Anthony and Kaipu Chang. There is no substitute for a mother, and there have been many times in this process that I could not be there for them except in spirit. Thanks to my parents, Jack and Louise McCue (the former deceased) for never giving up on me. Thanks to my Life Partner, Rev. Frodo Okulam and my housemate, Sally Cohn. When I stayed up all night typing, they stayed up too. To Dawn Wicca, I wish to say thank you for giving me the nudge that sent me back to school. Last, and perhaps most important, I want to acknowledge, 
in spirit, the woman whose waitressing career was the primary inspiration for this research, Violet McCue Milligan Bickford, "The Greatest Waitress Who Ever Lived." 


\section{TABLE OF CONTENTS}

PAGE

ACKNOWLEDGEMENTS $\ldots \ldots \ldots \ldots \ldots \ldots \ldots \ldots \ldots \ldots$ iii



\section{CHAPTER}

I INTRODUCTION $\ldots \ldots \ldots \ldots \ldots \ldots \ldots \ldots \ldots \ldots$

"Respite Community" Within the Urban Setting A Working Model $\ldots \ldots \ldots \ldots \ldots \ldots \ldots \ldots \ldots$

General Organization $\quad \ldots \ldots \ldots \ldots \ldots \ldots \ldots \ldots$

Notes $\ldots \ldots \ldots \ldots \ldots \ldots \ldots \ldots \ldots \ldots \ldots \ldots \ldots \ldots$

II LITERATURE REVIEW $\ldots \ldots \ldots \ldots \ldots \ldots \ldots \ldots$

Community as a Concept: Changing Foci in Social Science Research ............. 9

Toward Defining Community ........... 14

"Personal Communities" and "Cultural Scenes" ................... 14

"Community" in Four Case Studies . . . . . . $\quad 19$

Studies on Waitpeople $\ldots \ldots \ldots \ldots \ldots \ldots \ldots \ldots 24$

Urban Community . . . . . . . . . . 29

Conclusion $\ldots \ldots \ldots \ldots \ldots \ldots \ldots \ldots \ldots$ 
III THE CULTURAL SCENE AND APPLICATIONS TO WAITPERSON CUSTOMER INTERACTIONS



Identifying a Cultural Scene $\ldots \ldots \ldots \ldots \ldots \ldots \quad 37$

The Cultural Scene: Daytime Restaurants

in Downtown Portland ...............

The Setting:

Portland, Oregon, U.S.A . . . . . . . . . .

The Informants: Four Profiles

of Waitpeople

The Daily Grind

Customers and Customer Categories

in the Waitperson's Eyes ............

Conclusion $\ldots \ldots \ldots \ldots \ldots \ldots \ldots$

Notes $\ldots \ldots \ldots \ldots \ldots \ldots \ldots \ldots \ldots \ldots$

IV "RESPITE COMMUNITY"

IN AN URBAN RESTAURANT SETTING . . . . . . . 69

Two Restaurant Families . . . . . . . . . . 69

"The Respite Community" and "Family" ........ 72

Other Elements of Interaction $\ldots \ldots \ldots \ldots \ldots \quad 78$

The Gender Question ............. $\quad 78$

The Significance of Tipping . . . . . . . . . 79

The Joking Relationship ........... 81

The Position of the Waitperson

in the Family .............. 82

Conclusion $\ldots \ldots \ldots \ldots \ldots \ldots \ldots \ldots \ldots \ldots$

V CONCLUSION $\ldots \ldots \ldots \ldots \ldots \ldots \ldots \ldots \ldots \ldots$

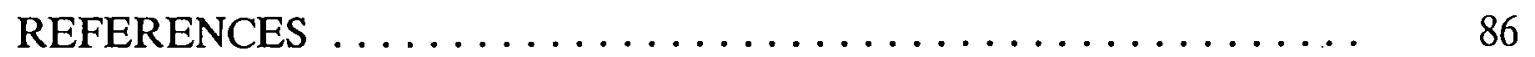


APPENDICES

A GLOSSARY: WAITRESS/WAITER TERMINOLOGY . . 91

B INTERVIEW QUESTIONS $\ldots \ldots \ldots \ldots \ldots \ldots \ldots \ldots$

C INFORMANT HANDOUT $\ldots \ldots \ldots \ldots \ldots \ldots \ldots \ldots \ldots$

D INFORMED CONSENT FORM ........... 104 


\section{PREFACE}

Several people stand outside a downtown restaurant on a gray April morning in Portland, Oregon. It is "drizzling"--that kind of precipitation too fine to be rain, too heavy to be mist. The dampness doesn't appear to bother the people, who are waiting for the restaurant door to be unlocked. They haven't even put up umbrellas as they wait for the beginning of their morning pre-work ritual. The hostess appears at the door, unlocks it, and welcomes the waiting coterie as it troops inside where hot coffee, possibly breakfast and a brief period of solitude await before the rigors of the work day begin.

It is 7:00 a.m. when this group of "regulars" tramps through the doors of this restaurant. Most of them come in every morning of the work week. Some of them sit in booths and at tables in the main part of the restaurant. This early in the day, most seat themselves at a long counter, a niche portioned off from the main section. They settle in to have their morning coffee, read the newspaper or visit with others at the counter, and with the waitress most of them know by name, as she knows them, and who is a part of their downtown community of acquaintances and friends. Most of her clientele here are white businessmen, although a significant elderly population of both sexes, also predominantly white, and including retirees from nearby businesses, regularly patronizes this restaurant. 
She greets all of them with enthusiasm, sees that they have their coffee and pastries, kids and jokes with them, sympathizes in some cases, fusses over them in others, calls them by familiar names, and frequently knows the names of spouses and children, and whether their dog is expecting puppies or their hot tub needs to be repaired. She notices if any of her more elderly "regulars" have been absent for a few days, and, if so, slips briefly away to call the number she has for that person. She checks on how that individual is doing, and if information needs to be passed on to the other "regulars" (i.e. Mary is in the hospital. Fred's arthritis is acting up; he would like visitors, since he can't walk too well right now.).

At the same time, down the street, the doors of another food service establishment open. Here, also, a band of "regulars" has been waiting to enter. This establishment contains several small franchise segments where customers may purchase food and drink, and a general seating area that services customers of all the franchises. Only two franchises are open this early: one specializing in breakfasts, and the other featuring pastries, gourmet coffee and espresso drinks. Two people are working behind the second counter, a man and a woman, both in their early-to-mid-twenties. The man has been employed here for about five years, and has first-name familiarity with most of these early-morning customers. He talks quietly with them while preparing their orders. Some of them give him scenarios of their previous day, or what they have been doing since they last saw him. They chat with him as one chats with a family member, or an intimate acquaintance, filling in details they seem to think he needs to know. Some ask 
him to pass information on to specific customers who will probably come in later in the day. The variety of customers here is greater than at the first establishment. In addition to businessmen and elderly, women, young people, and people of different racial backgrounds are seen.

Many of the customers here collect their coffee and/or pastries "to go", and take the items back to their work places. Others settle at the various tables. The counter at the end of the coffee franchise has a few stools that are always sought after and filled. "Regulars" compete with each other, and with non-regulars, for these spots which give them longer and closer access to "their" waitpeople behind the counter. Some "regulars" seem to assume that they should have first access to these stools, and balefully glare at anyone who "usurps" their spaces. They wait, hovering, for a counter stool to be vacated. One "regular", finally claiming one of the prized stools, lets the waiter know that not having had his accustomed morning "connection" (sitting at the counter) recently "ruined" his whole day. The close frequent regular contact this customer has with "his" waiter is more important to him than the items he has purchased to justify the contact in this setting. 


\section{CHAPTER I}

\section{INTRODUCTION}

In this thesis, I will draw from research done in a particular urban cultural scene to illustrate the foundations of a type of structure within the urban environment. I call this structure "respite community". " "Respite community" is a specifically urban phenomenon. It can be defined as a temporal, ad hoc, face-toface aggregate of people who seek temporary relief from social stresses and support through socialized interaction. The cultural scene used here to demonstrate the model includes a restaurant, a cafe, and one bakery/deli in downtown Portland, Oregon. The analysis of this scene is constructed from descriptions of the interactions occurring between waitpeople and their regular customers, in which a bonding process occurs. I believe this bonding to be basic to the creation of the "respite community" in the urban setting.

To speak of "creating community" might be taken to imply that there is a conscious intent on the part of the participants to build a specific interactional structure. Yet, a child, picking up a piece of clay, does not always know exactly what he or she wants to create, only that the desire exists to create something. In the same way the child uses the clay as a matrix through which something is 
created, the interactional matrix of waitpeople giving and regular customers receiving service can lead to the creation of the "respite community".

Serving and receiving food and drink at a commercial food service establishment is part of the American cultural experience. The restaurant, deli, cafe, and coffee shop provide an atmosphere in this context of service in which a kind of bonding can happen based on nothing more, in the beginning, than the sharing of a choice of location for the purchasing or serving of food and drink in a commercial restaurant location. This bonding in the urban setting, as I see it, often results in the development of long-standing social networks between individuals who have previously been strangers, and who, but for their chance meeting in this location, would never have become acquainted or interacted with one another anywhere else. Once established, such networks remain important to their members over a long period of time, and sometimes extend beyond the walls of the restaurant or deli where the initial contacts were made.

When I began collecting data, my goal was to learn about the work lives of waitresses and how their experiences, income, and job opportunities differed from those of waiters. However, I began to see a recurring interactional pattern between my informants and their customers, and recalled the same pattern from my own work as a counter clerk in a bakery deli from September, 1987 to March, 1989. I later saw the pattern again in the food service establishments in which I did approximately 85 hours of observations. Going back to the notes on restaurant observations I had taken in 1984 for a class on the development of 
ethnographic research, I found references to the same pattern, this time in a restaurant which catered heavily to elderly residents of the retirement complex in which the restaurant was located. I realized that the pattern remained constant, even though the individuals and the location differed, and that class, gender, and sometimes race differences did not seem to interfere with the pattern's existence.

I believe the relationships developed in this interactional pattern go beyond being simple networks, and become foundations for a sense of "community". The existence of the smaller, more intimate groups of associates, within the larger boundaries of urban interaction, has been mentioned "in passing" throughout the history of urban research in the social sciences, but its importance to the needs of its participants, and its significance in the overall scheme of urban culture has, I believe, been underestimated by academia. The importance of studying these relationships in the context of "community" within the urban setting is, I believe, to recognize the long-term value these small bodies have for their participants. The need to evolve pliant, flexible patterns of social organization that work in the context of our changing environments is of vital importance to human beings as individuals and as members of groups.

Most of the data on which this thesis is based was gathered between 1988 and 1991 from interviews with four waitpeople (two male and two female) and from over 85 hours of observation in restaurants in Portland, Oregon. Given the limitations on time, I focused on the day-shift, but recognize that such relationships can form outside that time-frame. The informants were chosen in 
various ways. I became acquainted with two of them because we were employed at the same place; I became acquainted with the third because I was a customer at his place of employment. The fourth responded to a notice I circulated soliciting waitress/waiter informants for this research project.

In addition, I have spoken informally with other individuals, including one woman who sat down at my table in the cafeteria at Portland State University, began talking to me, and was soon giving me her opinion of waitressing, based on fifteen years of experience in that work. She wasn't interested in being formally interviewed, however, because she had "put all that behind" her, and did not want to "think in that mind set" anymore. Working in food service is a form of employment many people experience at least once in their lifetime. I never realized how this fact would translate into the many people who have revealed "past lives" to me in which they were waitresses or waiters. Every one of these people had stories, but only four people volunteered to be informants.

Being an informant requires a certain amount of commitment to a research project, especially one in which the only remuneration is contributing to a body of knowledge. Not everyone who is willing to give the researcher a few minutes of time is interested in committing themselves to the work of explaining what they do, why they do it, and how they do it. Sometimes, the questions we ask as researchers must seem stupid to them. Sometimes they tell us so. However, those individuals who decide to give us a healthy chunk of their time and effort 
deserve far more of the researcher's appreciation than any of us can ever adequately express.

The interview data for this project was gathered through oral responses from the informants to a questionnaire with both structured and open-ended questions (See Appendix B). This vehicle provided a springboard for the informants to give further insights into their work lives. Limited time prevented me from conducting more interviews, even though several waitresses and one waiter have contacted me since the interviewing period has ended. (I hope to involve these potential informants in future research.) Nevertheless, the combination of informant interviews, participant observation, and review of pertinent literature has led me to propose the following model.

\section{"RESPITE COMMUNITY" WITHIN THE URBAN SETTING:}

\section{A WORKING MODEL}

As I will show, "respite community" in the urban setting, is composed of the following elements:

1. There is an aggregate of people who have in common at least one consistent meeting place where they gather on a regular (frequently daily) basis, and where they become acquaintances, then familiars, then participants in an on-going group. 2. All members of this on-going group get something from regularly coming together in this location and context that emotionally sustains and nourishes them. 
3. Each member is free, while participating in the group, to maintain her/his individual identity.

4. There is a consistent, though flexible number of regular participants, a constancy of interaction among them, and a lasting element of involvement of the participants with one another (Henry 1958).

5. Participation in this "respite community" is voluntary, with no coercion toward, or on the part of any involved individuals.

6. Individual members of a group may choose not to interact with other group members outside the specific location, even though participation in the group is important to each of them.

7. Certain behaviors are practiced, while others are not, based on the formal or informal consensus of the "respite community". The "rules" that govern group behavior are specific to behavioral understandings known only to the group's members.

\section{GENERAL ORGANIZATION}

The organization of this thesis will reflect the research segments I used to construct my model of "respite community" in the urban setting. In Chapter II, I will include a review of the literature that has contributed components to the above model, or which is relevant to the cultural scene of waitperson/regular customer interaction as it illustrates the model, including vignettes of waitpeople and references to the joking relationship, as it functions in a work environment. I 
will examine some ways in which "community" has been defined, and what some of its components are, as presented in examples from current urban anthropological research. I will demonstrate why the emphasis on urban "community" was a long time in developing, why it was overlooked in the context of urban culture, and how the "respite community" structure, as I see it in the urban environment, provides a solid and enduring support system for those urban dwellers who involve themselves in it. In Chapter III, I will discuss a cultural scene in downtown Portland, Oregon, which features interaction between waitpeople and their regular customer interaction in one restaurant, one cafe, and one bakery-deli. In Chapter IV, I will then apply the "respite community" model to the restaurant scene, and show how the elements of the model apply. My concluding statements will be contained in Chapter V. 
NOTES

1. The descriptive term "respite community" and the resulting definition emerged because of a discussion with Dr. Dan Scheans and Dr. Nanette Davis regarding what kind of "community" I was describing. Until that time, I used the generic term "community". 


\section{CHAPTER II}

\section{LITERATURE REVIEW}

\section{COMMUNITY AS A CONCEPT: CHANGING FOCI IN SOCIAL SCIENCE RESEARCH}

Early fieldwork in Anthropology (Boas 1927; Lowie 1925; Mead 1928) focused heavily on non-urban, non-industrialized cultures, primarily tribal and band societies. These were frequently cultures about which one might say that the term "community", when used to describe a social structure, would refer to spatial, geographic, or kin-based boundaries, groupings that remained fairly constant over time, with few changes in the groups that peopled them. Yet, the word "community" does not often appear as a significant descriptive anthropological term in these studies. Later inroads into the study of "folk" (Redfield 1937, 1955; Lewis 1951; Murdock 1949) and into peasant cultures (Lewis 1961,1966; Foster 1962; Wolf 1959, 1966) brought the concept of "community" more clearly into focus as a research concern, as well as introducing the influence of urban environments upon the non-urban cultures that became increasingly dependent upon them (i.e. Redfield's "folk-urban continuum" (Redfield 1955)).

Much of the earliest anthropological research on peasant societies was theoretically influenced by sociologists of The Chicago School. This School, whose 
members emphasized study of the urban environment, included Redfield's fatherin-law, Robert Park. Park, as one of The Chicago School's primary theoreticians:

depicted the city as a place that puts a premium upon rationality, upon the use of technical devices, and upon the development of unusual skills. City dwelling called for role specialization, competition, and the ability to accommodate rapid change. Urban groups were based not upon kinship but upon common jobs or interests. (Park 1915:585, 593, emphasis mine)

This theoretical approach was heavily borrowed by Redfield when he developed the folk-urban continuum. Redfield retained the image of the city as a corrupting influence on the "folk", using the folk-rural continuum to track the supposed fall from innocence of rural peoples as they came increasingly under urban influence (Redfield 1955; Press \& Smith 1980: 2-6).

I think it is important to emphasize that the common urban ground between Park and Redfield is the city of Chicago. While the hardships and negative aspects of the urban milieu cannot be ignored, I find it significant that one of the primary urban paradigms comes from social scientists directly relating to the problems of a city which was widely publicized for the extremes of its crime, hopelessness, anomie, and poverty, and that this paradigm became a major theoretical source for anthropologists who turned their research foci to the urban environment, or who, like Redfield, emphasized the negative influence of urban culture on rural peoples (Press \& Smith, 1980:4-6), and, for that matter, on all urban dwellers. While Chicago is an important urban center in the United States, and there are other faces to this city that do not reflect the criminal element nor the hardships faced by the poverty-stricken within its boundaries, it is certainly not 
the only significant American city, nor is it necessarily representative of the U.S. urban scene or of urban centers around the world. What can be said in favor of this negative emphasis on an urban setting is that social scientists were finally looking at urban culture as a focus of sociological and anthropological research.

As the research emphasis on urban cultural structures expanded in the Sixties and Seventies, ethnographers frequently depended on research models and theoretical models developed in previous ethnographic studies, especially those used to study peasant cultures. We have urban ethnographies that emphasize Redfield's (1955) "little community" approach, such as a hippie ghetto in Gainesville, Florida (Partridge 1973); Polish longshoremen in Portland, Oregon (Pilcher 1972); elderly Jewish people in Venice, California (Meyerhoff 1978); and Irish-Americans in South Boston (Shepar-Hughes 1981). Pilcher (1972), Meyerhoff (1978) and Shepar-Hughes (1981) focused on the survival of ethnic identity in the urban environment, particularly on the ways immigrants from specific cultures have adapted to the American City, and to what extent they do or do not maintain and pass to future generations the characteristics of their ethnicity that have kept them separate from the "melting pot" of American culture. In a recent ethnographic film, Elaine Velazquez (1990) has pursued similar information about the Americanization and urbanization of the Yiu Mien immigrants from Laos.

Immigration to the city by people from rural origins has contributed sizably to the current urban populations of the United States. Ambivalence on the part 
of these rural-to-urban migrants has been, for many of them, a price they paid for access to better-paying jobs and more opportunities. As George Foster has said:

Peasants throughout history have admired the city, and have copied many of the elements they have observed there. The city, with its glitter and opportunity, holds a fascination, like a candle for a moth. But at the same time, and for good cause, peasants hate and fear cities and the city dwellers who exercise control over them. (Foster 1967:10)

Since most ethnographies and social histories addressing the issue of ruralto-urban migration have done so from an ethnic framework (Siskind 1973; Woodham-Smith 1962; Potter 1960; Messenger 1969; Cole 1975), it is sometimes difficult to separate the immigrant from the peasant and ethnicity from origins and roots in a rural setting. Studies of rural America have likewise referred to the corrupting influence of the city (Lynd \& Lynd 1929, 1937; Warner 1949; Vidich 1958), while painting bleak pictures of the ultimate deterioration of small town/rural America being directly related to the influence of the nearby city.

The negative side of the rural coin paints the peasants as small-minded, selfish and resentful sorts who cannot stand for anyone to get more of anything. This "image of limited good" (Foster 1965) shows us a peasant who believes there is only so much of anything worth having, and that those who get more of anything will prevent him/her from getting his/her share.

If peasant studies have emphasized this "image of limited good", urban studies have been likewise visualized through the "culture of poverty" concept (Lewis 1961, 1966). Thus, there are many studies of the poor, the immigrant and the racial ghetto--sub-culture sets existing in the city. They portray the city as a 
behemoth, unconcerned about the needs of its little people--the poor, the working class, the single mothers, and the despised ethnic groups (Keiser 1969; Spradley 1970; Liebow 1967; Whyte 1943). Despite the negative lights in which these studies are cast, we begin to catch sight of adaptive, interactional structures that result from people living in the city over a period of time, rather than only reactions to moving to a new, alien environment.

The lure of the city to the farm boy has provided many a poignant plot for novelists and filmmakers. Granted, such stories have real-life counterparts, and residential change from a rural to an urban setting may produce culture shock. However, destruction of self-esteem and degradation are not automatically the result of moving from the country to the city, nor do negative experiences automatically punctuate the life of the urban dweller. The study of interactional structures in urban settings is significant, whatever the elements of urban culture are, because the majority of people in the United States, no matter what their ethnicity, class or original residential backgrounds, are living and interacting in cities.

However, research that continues to be based on the image of the urban environment as an enemy to humankind, as an environment in which people have no significance, is research that is done strictly against a backdrop of conflict between the resident and her/his environment. Such research only partly reflects the complex composition of urban culture. Certainly, conflict and violence exist in the city, but so do cohesiveness and cooperation. The urban environment does 
not reflect only one set of dualistic elements, but is the result of as many kinds of elements as there are people. The continual focus in research (as well as in the daily press) on crime and negative behavior places a large amount of emphasis on a problem that is only one element in the complexity of urban life and misses the rest. One of these elements, as we shall see below, is the creation of "community".

\section{TOWARD DEFINING "COMMUNITY"}

\section{"Personal Communities" and "Cultural Scenes"}

"Personal Communities". Jules Henry's work represents something of a bridge between the negative image of the city, and an attempt to observe the urban reality as its own cultural setting. In his book, Culture Against Man, Henry (1955) charts what he sees as the downfall of human dignity and morality in the United States. He describes a post-World-War-II American culture in which the acquisition of material goods is placed before the development of human compassion, where religious values are dying, where the American Dream has no room for the elderly and the disabled, and where traditional values that have kept immigrant people going in a new and frightening environment are not necessary to the individual succeeding in the urban setting. However, within this almost hopeless milieu, Henry also manages to trace a social structure through which urban folk appear to be developing new ways of bonding. It is his concept of "personal communities", developed in a later article (Henry 1958). 
Henry (1958: 53) describes "personal community" as " the group of people on whom an individual can rely for support and/or approval." His perceptions of this "personal community" as an "important social structure" encompass three vital components:

In the first place, a personal community has a certain number determined by counting those who most frequently contribute to an individual's welfare and approve his actions. In the second place, a personal community has a certain constancy, measured by the time spent by its members in direct interaction ... In the third place, the members of a personal community have a certain involvement in each other, that is to say, an obligation to give heed and be swayed by each other's wishes.

As Henry describes it, the "personal community" appears to be based on the creation of a consistent support system on which the individual member can depend, and to which he/she may turn for comfort, understanding, acceptance, and friendship. Henry's term for this composite of expectations is "reliance". As a child relies on its parents, and teenagers on their peers, so the urban dweller needs a group of people to whom he/she can turn as a humanizing influence to create a sense of community in what might otherwise be a dehumanizing environment.

I searched through two years of the American Anthropologist following the publication of Henry's article for responses to his concept. Neither articles nor letters addressing the issue of "personal communities" were forthcoming in that journal. Susan Emley Keefe (1980: 53), who drew upon Henry (1958) for her own research on urban support networks among Mexican-Americans and AngloAmericans states that the concept was "not immediately seized upon by 
researchers." Although anthropologists appear to have ignored Henry's ideas for a long time, the seed was planted in fertile soil. The subject would be revisited.

Community and "Cultural Scenes". A major difficulty with urban research is that studying structural organization in the urban cultural complex is a difficult task. To attempt a massive general study of an urban center would require team effort, and would probably result in a shallower study than one in which intense observation could be trained on a smaller segment of that culture. Such an indepth examination of what Spradley (1970) calls a "cultural scene", is more practical for the individual researcher. A "cultural scene" may take in one portion of the urban dweller's life: the check-out line in a supermarket, for example, or a monthly gathering of the Society for Creative Anachronisms, or it might focus on people who move within a certain setting. In either case, the research setting of the "cultural scene" gives the researcher the opportunity to concentrate closely on a very specific slice of human cultural interaction within a larger framework of social organization.

Spradley's use of the "cultural scene" has had a profound methodological influence on urban anthropological research (e.g. Partridge 1972; Pilcher 1972), as well as providing a foundation for ethnographic work by both Spradley and his students (Spradley 1970; Spradley \& Mann 1975; Spradley \& McCurdy 1971, 1972). One of Spradley's ethnographies applied the "cultural scene" approach to a study of transients caught in the vicious cycle of the municipal justice system in Seattle, Washington (Spradley 1970). Another portrayed cocktail waitresses, 
arrogant bartenders and strutting football players in an urban bar (Spradley \& Mann 1975). It is the bar scene that provides a setting with characteristics relevant to my own search for a concept of community.

"Brady's Bar" served a working class population during the day and a college crowd at night (Spradley \& Mann 1975; Mann 1976). Spradley and Mann examined the scene from the vantage point of the cocktail waitresses, "Brady's Girls", who work there, and their interactions with and attitudes toward customers, the bartenders and one another. The cultural context of this scene is used by the researchers to demonstrate that the behavior patterns of the primary "actors" in the "scene" emphasize what Spradley \& Mann see as the transference of a woman's role in the home to her role as a cocktail waitress, while acknowledging that the behaviors, themselves, are culturally determined within a wide variety of human behavioral possibilities (Spradley \& Mann 1975: 4-12). The people at "Brady's Bar" come together, get acquainted, and bond, based, to begin with, on their presence in a specific atmosphere. Not everyone who comes into the bar is integrated into the core. Some are more "in" than others. Something more lasting, more constant, is being created. In keeping with James Spradley's concept of the "cultural scene", the environment of the bar conforms to a setting in a complex society in which:

people do not share their culture with everyone else and...on one level at least, culture does not integrate their total way of life. (Spradley \& McCurdy 1972:23) 
There are people who "fit" and people who don't. There are "regulars" and there are "real regulars", and there are "people off the street". Not surprisingly, these divisions within the bar crowd also turn out to apply to the restaurant/cafe patrons and waitpeople I studied as well. The concepts of "regular" and "real regular" proved to be very useful aspects of Spradley \& Mann's (1975) study in relation to my own research.

The Joking Relationship in the Workplace. Some of the interactions which Spradley \& Mann found in "Brady's Bar" are best described as constituting a joking relationship. Such relationships have a particular function in the workplace.

members of low status may sometimes purposely joke with members of higher status partly because it gives them a sense of bravado and partly perhaps because by means of it they are able to assume at least temporarily an equality of status with those whom they are addressing. (Bradney 1957:184-185)

I found that some descriptions and analysis of the joking relationships between cocktail waitresses and other employees, and between employees and customers of "Brady's Bar" related directly to the waitperson/regular customer dyads I observed. The main difference between these joking relationships in "Brady's Bar" and in the establishments I visited is in the frequent allusion to sexuality and the use of sexually provocative banter Spradley \& Mann recorded in the bar. Such language and allusion did not occur as openly in the restaurant/cafe settings where I did my observation. This is not to say that such behaviors would not ever be found in restaurants, simply that they were not regular features where and when I did my observations. 
Joking can be used to mitigate conflict. In the descriptions of "Brady's Bar", there are references to mock "battles" between waitresses and bartenders who are not getting along, or in instances where the waitress is having problems enduring the "macho" attitude of the bartender. These "battles" do not result in harm coming to anyone. They function as a means to release stress and possibly to entertain customers present at the time. There are undercurrents of conflict present, but the acting-out behavior helps to temporarily resolve tension between the "combatants".

Joking is also a way of making a potentially oppressive situation more bearable. When institutionalized inequality exists between two individuals or groups in the workplace, joking is one of the most effective ways to keep the tension caused by that inequality from rising to a level where overt conflict may occur (Bradney 1957). Pilcher (1972) documented a working class longshoremen scene over a twenty-year period that included a major strike. He focused on the joking relationship as a means of releasing stress in the workplace, and as a method of expressing a kind of camaraderie on and off the job, between conflicting factions (e.g. workers vs supervisors, Blacks vs Whites), and during social events involving off-duty co-workers.

\section{"Community" in Four Case Studies}

There is a great deal written in academic journals about solutions to "the" problems of the city, e.g., housing, job development, urban renewal, urban sprawl, gangs, urban flight, homelessness, poverty and drug peddling. However, most of 
these journals do not address the sense of community identity among urban dwellers, except in the context of economic development or political/municipal structures. Because my research was done with waitpeople and customers of restaurants, delis and coffee shops, I checked restaurant and food service journals, but, with the exception of occasional graphics in advertisements, the focus was on how to make more money by making meals and restaurant environments more attractive to "better" clientele. It seems that the restaurant industry has little awareness of its significance to the informal social networks that food service establishments contribute to the urban sense of "community", despite the fact that such knowledge might contain useful marketing material.

I finally found articles that relate directly or indirectly to the sense of "community" I had been trying to articulate. These came largely from literature on urban anthropology. A study by Keefe (1980) discusses friend-based and kinbased support networks among Mexican-Americans and Anglo-Americans in urban communities, and the growing importance of friend-based networks among Mexican-Americans not born in the old country. My study does not focus on kinbased networks, but the friend-based network is significant, and is implied in my model of community. Keefe's (1980) study uses data gathered in three Southern California communities: Santa Barbara, Oxnard, and Santa Paula. She finds small family- and friend-based networks of exclusive Mexican descent among those of Mexican birth. For Mexican-Americans born in the U.S., she finds the network has enlarged, is still kin-based and friend-based, but with friendships outside, as 
well as inside, the Mexican-American community. Anglo-Americans, she finds, have support networks that are exclusively friend-based (51). Keefe's emphasis on the increasing importance of friend-based groups is significant to my own emphasis on the friendship basis of the "respite community".

Keefe draws on the concept of "personal community" as put forth by Henry (1958) to make her analysis of how each group creates the networks needed, developing a sense of mutual support in three urban settings. She emphasizes the importance of friend-based networks in an urban setting, particularly among those born in this country, and not as connected to the parent country. Because Keefe's use of Henry's concept worked, I, too, turned to the "personal community" model, adapting some of its components for elements of my model, and incorporating, whole cloth, those components that seemed to need no reworking to fit directly into the model.

In Hazan's (1984) study of an analysis done in Tel Aviv, Israel to determine the cause of failure of a government-sponsored urban renewal program (Hazan 1984), I found supporting evidence for a perception of "community" based more on interaction than on race and kinship. Hazan's data was gathered in the poverty-stricken, culturally diverse Tel Aviv borough of Arod. The designers of the government-sponsored program, did not live in the borough, and thus were not sensitive to the cultural and economic composition of the borough. In addition, the designers' perceptions of "community" reflected their Zionist philosophy and commitment to a specific spiritual belief (Judaism) and were based 
on their perceptions that residential location and continuity of regular interaction with one's neighbors were hallmarks of "community" for the residents of Arod. These perceptions and philosophies were not necessarily shared by the borough's residents, who, instead, saw "community" as being kin-based and friend-based, with most of the latter not located in the borough, but in the workplace and its nearby environment (Hazan 1984). The results of Hazan's study support my thesis, which connects the bonding I call "respite community" in an urban setting to the experiential elements of the daily lives of the people, rather than to residential location.

A study conducted in Cracow, Poland proposes three levels of structure in an urban setting: "urban macrostructures, structures of medium range, and microstructures (Frysztacki 1983: 263)." This study is significant to my research, because of the importance Frysztacki attaches to microstructures and to what he calls "informal associations" in the urban setting. He considers both of these to be foundations for social networks among urban dwellers. Microstructures:

manifest themselves in individual actions, social actions and relations, in particular groups in which there is a domination of direct and personal relationships. (Frysztacki 1983: 265)

Frysztacki proposes that three types of social groups comprise the primary elements of urban microstructures: family groups, neighbor groups, and various forms of associations. He divides the third element further into two subcategories: formal associations and informal associations, stating:

First, associational relations and groups are built along two, clearly distinguished lines. Informal associations come into being as a result 
of individual choice of partners and are actualized in non-institutional frames of private life, while formal associations unite groups characterized by at least certain statutory regulations. Secondly, informal associations are more important than the latter in the context of urban structures. (Frysztacki 1983: 267)

Although he acknowledges the continuing importance of families, Frysztacki recognizes that urbanization and a move away from the multi-generational family has led to informal associations acquiring increased significance for the urban dweller as: "a stabilizing influence on individual participation in urban life" (Frysztacki 1983: 269). The "respite community", as I have described it, began to clarify as a model because of the merging I did between Frysztacki's "informal relationships" and Henry's "personal communities".

Finally, an article on the cultural management, arrangement and use of urban public space (Eames \& Goode 1980), includes discussion of interactions between members of groups that meet regularly in public settings. Establishments that dispense food and drink, such as tea shops and taverns, are included as a type of setting described in the study. These settings are:

focal points of shared identity and concerns. . [ [which] provide the only means of mutual access to individuals with otherwise divergent interests, ethnic backgrounds, and economic status. (Eames \& Goode 1980: 337)

In addition the authors refer to interactional cues that function as informal rules of social interaction between group members, as well as indicating barriers to outsiders.

there are strict rules governing the interactions taking place, and people who do not know the rules are frequently ignored, ridiculed, or kept outside. Several segments of the urban social structure may 
regularly interact in these places, as in ethnically heterogeneous neighborhoods or occupationally heterogeneous marketplaces, but the localized rules for such interactions are known only to regulars in these spatial areas. (Eames \& Goode 1980: 339)

While this example is applied by Eames \& Goode to identifying "members of the group" versus "strangers", the suggestion that rules exist among members of these informal groups, and that those rules govern interactions between members is significant to the element in my model that discusses rules of social interaction. The "families" appearing in my data can be so described.

In the above studies, researchers documented social structures that provide important informal networks of support and group identity for participants in those groups within the urban environment. Each of these networks is small in comparison with the urban boundaries in which each functions, but each represents a whole: a body through which members gain and give support and find a sense of unity. Through this unity each individual builds foundations for a context through which to relate her/his life to the urban environment in which she/he lives.

\section{STUDIES ON WAITPEOPLE}

Published academic sources on waitresses and waiters are few. There is more written about waitresses and waiters in novels and folklore, it appears, than there is in published social science scholarship, even from feminist scholars, from whose perspective one might expect more interest. I found only four sources (Donovan 1920; Spradley \& Mann 1975; Terkel 1972; Wood 1979) that provided 
detailed observation and/or analysis of waitresses and their work environment, and only once source (Mars \& Nicod 1984) that similarly focused on waiters.

In The Woman Who Waits, Donovan tells about temporarily abandoning her middle class world after World War I to go "underground" into the world of the waitress. She documents her experiences of nine months during which she works as a waitress, learning the skills of waitressing and becoming acquainted with women who would be performing this work most of their lives. Why waitresses? For Donovan, in the nineteen twenties, waitresses represented:

the advance guard of working women who are marching steadily deeper and deeper into the world of economic competition, getting into new and dangerous contacts. The movement of women out of the home into the world began long ago. Since the war (World War I) they have gone forward into the shop, the factory, and the office at a more rapid pace than ever before. There is now no talk of "back to the home." The war has made conclusive a revolution that had already begun. (Donovan 1920:14)

Donovan's record of interactions between herself and customers as a waitress, and as a co-worker with other waitresses is interesting and useful, and she makes a point of emphasizing the importance of being able to communicate well, to "jolly with the customers", especially if they are men (68). There is relevant information in Donovan (1920), even if some of it is outdated, although I found her overall evaluation of career waitresses to be so derogatory as to render the source difficult to use. She heralds waitresses as being in the vanguard of the growing female work force, at the same time expressing a judgement that the very women she pedestals are also subject to her moral evaluation of them in which she finds 
them lacking by her standards. Typical of the opinions she expresses about waitresses is the following:

There is not much that is complex about the waitress and her behavior can easily be reduced to the two fundamental appetites of food hunger and sex hunger. She is intelligent, efficient, industrious, dishonest, and dishonorable, loose in her sex relations, impatient of the restraints put upon her by the members of the group from which she came (parents, relatives) and inclined to set up new standards for herself and to make a new group life in which these standards are approved. (145).

The second available study of waitresses, The Cocktail Waitress (Spradley \& Mann 1975), has already been discussed above. The waitresses, "Brady’s girls", are scrubbed, well-mannered, well-educated young women, who are mainly white, middle class college students who will probably not be waitresses after they finish their college educations. I have used this source more for its relevance to the concept of community than for its portrayal of waitresses. Although it represents the cultural scene of bars, it does not refer to waitressing as a career choice but as a temporary job to make ends meet until the young women have finished with college. The exception, Sharon, is depicted as holding this job more for fun and a sense of community than because she plans to remain a waitress. In fact, she holds an office job, as well. Since my initial intention was to search material on career waitresses, I found Spradley \& Mann (1975) less useful as a resource on women who would be waitressing as a long-term employment option.

Woods (1979) provides one of the few fragments of feminist writing that discusses the waitress experience from the waitress' point of view. The concentration in this article is on how, given the external controls put on food- 
servers by management and societal expectations, women working as waitresses might empower themselves on the job. In addition to citing her own waitressing experiences, Woods talks with other waitresses in western Massachusetts, in an area she describes as "semi-rural". She says: "social attitudes are fairly conservative. . . there is little strong pro-union sentiment" (83). I have been able to apply information from her article to what has been told me by waitress informants. Her discussion of tips and their effect on service is especially interesting.

The final source on waitresses to be discussed here is a vignette by Studs Terkel (1972). Interviewing working people throughout the U.S., and eliciting their opinions of their jobs and their feelings about their on-the-job experiences, Terkel finds Dolores Dante. Dante has begun waitressing because she and her three children have been abandoned by her husband, and she has to become quickly self-supporting. "I became a waitress," she says, "because I needed money fast and you don't get it in an office" (Terkel 1972: 294).

Dante, like many working class women, doesn't have time to formally train for a paying job. She enters an occupation in which work is immediately available. She takes pride in the work she does. She does not find being a waitress to be demeaning work. In fact, she expresses contempt for those who look down on her for doing the job she does well, and who are surprised that a woman of such obvious intelligence could choose to remain a waitress. Dante says:

Everyone wants to eat, everyone has a hunger. And I serve them. If they've had a bad day, I nurse them, cajole them. Maybe with coffee 
I give them a little philosophy. They have cocktails, I give them political science ... I have an opinion on every single subject there is. In the beginning it was theology, and my bosses didn't like it. Now I am political and my bosses don't like it. I speak sotto voce. But if I get heated, then I don't give a damn. I speak like an Italian speaks. I can't be servile. I give service. There is a difference . . . People imagine a waitress couldn't possibly think or have any kind of aspiration other than to serve food. When somebody says to me, "You're great, how come you're just a waitress?" Just a waitress. I'd say, he's not worthy, not that I'm not worthy. I don't feel lowly at all. I myself feel sure. I don't want to change the job. I love it. (294-295)

Dante's responses indicate that she is aware of her significance in the lives of the people who come to her for service and more. She knows her worth, is aware of the world around her and those who people it. She can fit herself into discussion on a multitude of topics that are of interest to her and her customers. She also represents a confidence I have found in women who have waitressed for a long time. Even though there is a managerial hierarchy with authority over their hiring or firing, and they are aware of this hierarchy and are minimally deferential to it, they know that their primary relationships on the job are with their customers, and maybe with other waitresses and waiters. The employers are frequently on the scene at least part of the time, but are seldom significant to the waitress' daily interactions on the job. The difference between the Dolores Dantes and "Brady's Girls" is experience and an accompanying professional confidence.

Mars \& Nicod (1984) examine waiter/customer and waiter/co-worker interaction in the context of a cultural scene of waiters who "work" restaurants in resort hotels in England. Their main focus is on how the waiters, cooks, etc. take 
advantage of the resources available to them, and on how the pilferage network functions: how pilferage is accomplished and enhanced based on one's status in the waiter/cook hierarchy, and the "games" one can play. The customer is portrayed as yet another lamb to be fleeced, and no real network ever appears to have been established between the waiters and their customers. If there were any significant instances of community building efforts between customers and waiters involved in this scene, they weren't evident, which was a disappointment to me because it was the only ethnography on waiters I could find. The waiters were portrayed as opportunistic money-grabbers who would use any means, legal or illegal, to line their own pockets. On the other hand, the three works on waitresses discussed above reveal a sense of unity between waitpeople and their customers. As we shall see in Chapter IV, this sense of unity can be created with both waitresses and with waiters.

\section{Urban Community}

Earlier, I suggested a seven-component definition for "respite community" as I am using it in this thesis. When I use the term "community" in discussing the urban Portland restaurant scene, I do not mean the same thing as people do when they refer to the Community (Black, Hispanic, Jewish, etc.) These ethnic groups can, without doubt, form communities within urban settings. They are based on racial, ethnic, and/or religious ties, and have the ability to become more corporate groups than what I mean by "community". It is also possible for people of like or similar ethnic background to live in the same neighborhoods and not 
develop a sense of community with one another, or to form their communities using different means of choosing those affiliations that result in that sense of community.

Researchers cited above (Frysztacki 1983; Hazan 1984; Henry 1958) have pointed to the existence of long-term informal bonding in the urban environment that is not related to kinship, ethnicity, race, or magico-religious practices based on formalized structures to which their participants are bound by tradition and obligation. I am not questioning the importance and validity of these more formal or corporate structures, only suggesting that they are not the only important structures in the urban environment, and are frequently not even the most important structures in the lives of individual urban dwellers.

The "respite community", as I have come to see it, is reflected in an atmosphere in which a body of people, small or large, voluntarily forms a regularly interacting group in which co-operation and mutual emotional support occur on a regular basis, but not necessarily in a full-time context. "Cultural scenes" reflecting this "respite community" may differ from one another in location, in size, in the amount of time participants spend together, and in the composition of the membership (e.g., race, gender, age, lifestyle, class). However, in all cases, participation in this type of community provides a milieu in which each individual participant experiences and dispenses acceptance, interest, and inclusiveness. Use of the "scenes" that will be described later as examples of the model does not imply that the kind of "community" suggested by my model can only be found in 
restaurants, coffee shops and delis. These settings are used to provide a context through which the model can be illustrated.

This section will focus on the concept of the "respite community" and how it may be applied in general ways that specifically reflect the urban setting. Webster's Third International Dictionary defines "community" as:

social activity marked by a feeling of unity but also individual participation completely willing and not forced or coerced and without loss of individuality ... there must be conscious and positive sharing. (1969: 460)

A community, by this definition, is based on an atmosphere in which its members generally get something that sustains them, and guarantees that each one may maintain her/his individual identity. This is a fairly broad definition, especially when we are examining the concept of community using examples in which dyadic interactions within small group structures are important foundation stones of the concept.

It is important that we be able to distinguish between the kinds of interactions that take place in the observation setting, asking which kinds of interactions may be seen to suggest "community", and which ones are simply interactions. More specifically, when does an interaction lead to closer, more bonded involvement between individuals, and when does it meet the need of the moment without leading to a strengthening of ties between those who have interacted? Can we determine, by the quality or type of interaction between a person ordering a cup of coffee in a restaurant and the waitperson who serves her or him, whether or not there is something existing between these two individuals 
that goes beyond simple waitperson/customer interaction, and that can later be shown to be the first stone in the foundation of "community"? To begin to consider such questions, we must expand the above definition, and this will be pursued by applying it to our suggested model for the "respite community" from Chapter I.

First, there is an aggregate of people who have in common at least one consistent meeting place where they gather on a regular (frequently daily) basis, and where they became acquaintances, then familiars, then participants in an ongoing group. Reference has already been made in the literature section above to people who meet frequently, in small groups, in a consistent setting (Spradley \& Mann 1975; Frysztacki 1983; Eames \& Goode 1980), although not all of these groups could fit into all the elements of my model. A consistent meeting place, however, is a must in order to provide the locational setting in which the bonding occurs. Members of the interactional "community" need a place where they can meet, check in with one another, spend time in conversation, and engage in whatever surface activity brings them to this location in the first place, whether it is drinking coffee, making ceramics or playing Dungeons and Dragons. We need the "community center" in order to contain the "community".

Having established that there is a need for a place, we now need to determine that all members of this on-going group get something from coming together in this location and context that emotionally sustains and nourishes them. This element is difficult, if not impossible, to evaluate, because its effects are 
abstract. We cannot measure motivation, companionship, trust, friendship, love and loyalty. There is no valid scale. Yet, because these groups have no set social, economic, or political goals, we can infer that part of their function must be the provision of personal emotional support.

Each member is free, while participating in the group, to maintain her/his individual identity. In a "respite community" that accepts its members as they are, there is little need for the participants to pretend they are something they are not. Role-playing may occur, but it is not something imposed on the "actor" by the other members of the community, but is his/her conscious choice. The atmosphere that imposes no particular role expectations on its members may be, in turn, more likely to attract people who want to have the freedom to act according to their own self-images, not someone else's image of them.

Now we have a regular meeting place, with an atmosphere that provides emotional support and acceptance, and it follows, in this egalitarian setting that there is a consistent, though flexible, number of regular participants, a constancy of interaction among them, and a lasting element of involvement of participants with one another (Henry 1958). Each time a "respite community" appears in the context described by my model, there is a core around which its participants collect. Most of the members of this core spend a significant amount of time at the meeting place, although none of them are present at all times that the whole congregates. Over time, members may leave or join, but the "respite community" itself continues as if it has a life of its own. This element is reflected in Henry's 
(1958) model, in which he implies the existence of on-going, regularly-meeting groups from which members get support, and on which they can rely. Frysztacki (1983) implies that a certain stability is created through these regular gatherings of friends, a stability that outlives marriages, careers, and relocation of individual members within the urban boundaries.

Participation in this "respite community" is voluntary, with no coercion toward, or on the part of any involved individuals. People are free to come and go. Other members may not wish to see their friends leave, but there are no requirements in this "respite community" structure that force any participant to remain if he/she wishes to leave. The chosen absence may be permanent or temporary. Likewise, the member may choose to return. Another part of this element is that the "respite community" does not have to provide any individual with her/his entire experience of "community". There may, in fact, be more than one such type of community that one individual experiences at a time.

Individual members of a group may choose not to interact with other group members outside the specific location, even though participation in the group is important to each of them. One of the functions of a "respite community", existing as it does in a small setting like a restaurant or coffee shop, is to provide a place away from the rest of an individual's life experiences. Participants in such a body may see it as a special "world", one in which he or she can throw aside the expectations others have of him/her, and because that separateness or uniqueness is so valued, the individual member may not wish it to come into contact with the 
other elements of his/her life. There are, of course, "respite communities" in which the members choose to be involved with each other outside the meeting place, but it is not a requirement for participation or for acceptance by the other members of the group.

It is unlikely that a community would exist without expectations or "rules". In this case, the "rules" are not written down, nor enforced by officials. However, certain behaviors are practiced, while others are not, based on the formal or informal consensus of the "respite community". The "rules" that govern group behavior are specific to behavioral understandings known only to the group's members. No matter how informal the ties are that hold a community together, there are always rules. In a community of choice, the rules are frequently implied, not declared, but everyone knows, or comes to know, what is done and not done. In a community where the rules are benign and do not interfere with the free choices and identities of its members, the rules are applied on the basis of consensus. Eames and Goode (1980) refer, in their discussion of "public places", to the rules that those who regularly interact know well. They suggest that only those who are members of the in-group know the rules, but that those on the outside know they are on the outside. Knowing the rules, then, is an important step toward being a full member of a community, but it is as important to know the why of the rules, and that they are rules of unification, not of exclusion. They come from the experiences of the participants, and are not imposed from outside the group, nor by its "leaders". 


\section{CONCLUSION}

This section has revealed several defining factors of the model of "respite community". An urban "respite community", in the smaller, more intimate sense, can be reflected in the regular interactions of people who meet often, at particular times, in the same location. As such, it is a structured body, despite (or perhaps because of) its small size and informality. Structures that are more societally recognizable, actual segments of the urban milieu, reflect single elements as foundations for bonding (e.g., the Black Community, the Buddhist Community). Although these are segments where formalized bonds can exist, they may, because of their size, be more impersonal and lack the sense of supportiveness that the definition of "respite community" implies. In the restaurant family, we will see a type of social organization that exemplifies that smaller-scale, more personal structure with none of the trappings out of which "community" has been traditionally assumed to develop.

The next section will draw this material and my observations and informantgenerated data together in a discussion of what constitutes the "respite community" in an urban "cultural scene" that has, as its setting(s), restaurant culture in downtown Portland, Oregon. 


\section{CHAPTER III}

\section{THE CULTURAL SCENE AND APPLICATIONS TO WAITPERSON/CUSTOMER INTERACTIONS IN DOWNTOWN PORTLAND}

\section{IDENTIFYING A CULTURAL SCENE}

Much current social science research is done in the matrix of urban culture and complex societies. As we saw in Chapter II, Spradley's development of the "cultural scene" as a model of research methodology is, in part, an attempt to scale urban research projects down in size, focus, and time requirements (Spradley \& McCurdy 1972). The "cultural scene" approach focuses on and brings forth for examination, segments of current cultural practice that frequently fall, unnoticed, into the background of a complex cultural milieu.

Theoretically, the "cultural scene" as a research tool takes its inspiration from ethnographic semantics, in which the aim, according to Spradley \& McCurdy, is "to describe a culture in its own terms...", and "...to discover the characteristic ways a people categorize, code, and define their own language" (viii). It is not enough for the ethnographer to observe the scene and question informants. $\mathrm{He} / \mathrm{she}$ needs to come to an understanding of the world view coming from that scene couched in the language and perceptions of the scene's regular "actors". 
A cultural scene is the information shared by two or more people that defines some aspect of their experience. Cultural scenes are closely linked to recurrent social situations. The latter are settings for action, made up of behavior and artifacts that can be observed by the outsider; the former are the definitions of these situations held by the insider. (24)

To establish the probable existence of a particular "cultural scene", it is necessary to isolate consistent behavioral patterns, the regular repetition of which establishes a predictable set of actions and interactions. The "cultural scene" model adapts well to the urban setting, while not claiming to be representative of the whole urban culture, or even a sizable portion of it. Spradley says:

It is possible to choose a bounded localized group such as a neighborhood as the focus of study. The problem with such a decision is that, unlike the members of simple societies, the residents of a neighborhood in our cities share only part of their cultural knowledge. They go to different churches, work at different jobs, pursue various amusements, believe in a host of varying solutions to our national problems, and generally differ in an enormous number of ways. In short, neighbors share only a limited number of cultural scenes. They know about their locality, rules for polite behavior and English grammar, and they abide by many of the same implicit premises about life. But the cultural knowledge they do share must not lead us to overlook their differences. (25)

We are confronted here with two facts of urban reality. First, the "actors" in the "cultural scene" share a number of perceptions and experiences, but don't necessarily share all of them with the other actors in the scene. Second, the people in our urban neighborhoods are not necessarily involved in our own "cultural scenes". We may be acquainted with our neighbors and know how to communicate with them on a superficial level, but we may not really "know" them. 
If, however, after using Spradley's method, the researcher is tempted to fit all the cultural scenes together--to form a "gestalt" of urban culture--he/she will discover that Spradley has not offered us a means by which to plug all the cultural scenes into a larger pattern. Indeed, he demonstrates no intention of doing so, allowing the cultural scene to stand alone. What makes the "cultural scene" a manageable model for ethnographic research, and permits the ethnographer to examine a smaller segment of culture in greater detail, however, also implies a trust on the part of the ethnographer that the information given by the informant(s) is truthful. Yet, there are certainly instances in which informants have misrepresented themselves in a research context (Moody 1971). ${ }^{1}$

No matter how narrow the focus of a "cultural scene", whether it is a third grade class (Doyle, 1972) or an urban jewelry store (Mann 1972), it is a legitimate microcosm, and therefore worthy of ethnographic interest. We need not compare the third graders to eighth graders, nor the jewelry store to a stationary store. Each scene stands alone as unique and of interest by its own fact of existence, and does not per se require connection to any other scene. However, the problematic issue that emerges because of this narrow emphasis is when the "scene" is identified, either by the ethnographer or the readers of her/his work, with a larger cultural milieu.

I am still convinced of the usefulness of Spradley's model, and have applied the "cultural scene" approach to three different establishments (a restaurant, a bakery-deli and a multi-franchise cafe), building the scene to embrace three 
different perspectives (worker, customer and interviewer). I find that many of the methodological techniques used by Spradley to investigate "cultural scenes" can serve as helpful guidelines in what to include and what to ignore, and how to look at the data gathered. I drew directly from Spradley's suggestions on developing approaches to informant interviewing (Spradley 1979; Spradley \& McCurdy 1972) to design the three sets of questions I developed and used for interviewing informants. Following Spradley \& Mann (1975), I have also collected a partial list of terminology used by waitpeople (Appendix A), and created a waitpersongenerated classification of customer types, out of which emerged the restaurant patron group that forms the basis for my research, and that resembles the group of "real regulars" known as the "Brady's Family", at "Brady's Bar" (Spradley \& Mann 1975).

In recording the "grand tour" (as Spradley [1979] calls it), I generalized a typical schedule for restaurant patronage during the day in three restaurant establishments, one which is probably also typical of Portland's downtown restaurant scene. This schedule, in turn, helped me pinpoint times of day when the members of these groups were likely to be present, or at least more consistently present in larger numbers, at their favorite restaurants. This, in turn, made scheduling observations easier for me. 


\section{THE CULTURAL SCENE: DAYTIME RESTAURANTS IN DOWNTOWN PORTLAND}

\section{The Setting: Portland, Oregon, U.S.A.}

Portland, Oregon, is the largest urban center in the state of Oregon, located in the Pacific Northwest of the United States on the western coast of North America. The U.S. Census of April 1990 documents Portland's urban population at 437,319 people. As the center of a five-county metropolitan area (including Multnomah, Clackamas, Washington, and Yamhill counties in Oregon, and Clark County in the state of Washington), Portland's resources serve a metropolitan population of $1,477,895$. The bulk of Portland's land mass sits at the confluence of two large riverine systems, the west-flowing Columbia River and the Willamette River, which flows north through the Willamette Valley of Oregon. Because of its geographical location, Portland is the site of a major fresh-water port in the Pacific Northwest, with primary industries being wood products, agriculture, and tourism (Pilcher 1972:8-10).

From the location of a Hudson's Bay trapper's cabin in 1828, Portland evolved into "Little Stump Town", then to Portland in the mid-1800's, because its location was ideal for the development of a port and mercantile center. Linking the southern Oregon farming and fishing communities with the livestock-rearing and agricultural territories of Eastern and Central Oregon, Portland became the gathering place, the cultural center for the state of Oregon. 
Restaurants have always played a significant part in the social atmosphere of Portland, and the Portland community has always taken pride in having a thriving restaurant scene. Percy Maddux (1952) describes Portland as a city where even the severe winter storm of December 1884 could not close the restaurants and saloons of the city (125). What was true in the 1880 s is equally true today. Portland is divided into a number of neighborhoods, each of which has its own distinctive characteristics. In the 1800 's, many of these neighborhoods, such as Albina, in the north/northeast part of Portland; Sellwood, on the city's far southeast side; and St. John's, on the northern rim of the city, were small communities which eventually merged into the Portland municipality. The Willamette River serves as the boundary between east and west Portland, with Burnside Street as the city's north-south dividing line.

The core area of downtown Portland begins at the Willamette River on the east, extends north to Burnside, west to 12th Avenue, and south to around Jefferson Street. There are theaters for live performances, such as the Winningstad Performing Arts Center ("Winnie") and "The Schnitz" (the Arlene Schnitzer Concert Hall), and first-run theaters, like the recently rebuilt Broadway Theater. Hotels located in the downtown area (i.e. the Hilton, the Benson, and the Heathman) cater heavily to the tourist and business trade. Most have restaurants and lounges that draw local patrons, as well.

Major mercantile operations, like Meier and Frank's, Nordstrom's, and the recently-completed Pioneer Place surround the plaza-like Pioneer Courthouse 
Square, one of the most popular gathering places in the city, whether for summer rock concerts, for political rallies, or as a "hang-out" for the "streeties" (street youth). "The Square" is the hub of downtown Portland, and clustered within easy walking distance are scores of restaurants, coffee shops, cafes, delis, and sit-down bakeries. The variety of food-service establishments runs the gamut from the elegant French restaurant to the "greasy spoon", with considerable ethnic variety, as well. The city has been described by Kathy Smith as "user friendly," by Francine Siegal, M.D. as "an inviting city to walk around", and by Dr. Judith Ramaley as "quiet, intimate, touchable" (The Portland Downtowner, June 24, 1991: 14).

Small in comparison to other cities, Portland has cultivated an atmosphere that balances a sylvan, rustic nature (Portland's largest park, Forest Park, in the city's west hills, covers 40 miles within the city limits) with the cosmopolitan sophistication of an international port and artistic center. Like any other urban center, Portland has its criminal element, and city-wide concern exists about the expansion of urban gangs and increased drug trafficking. Urban problems don't disappear, even in an urban center that has been called "an exceptional city in which to live with the nation's most livable environment" (Walter W. Cole [aka Darcelle XV]: 15).

The scene that is reflected during daytime hours in downtown Portland is of entertainment, mercantile operations, and daily employment for thousands of people. The diverse work population of the downtown area includes office 
workers, business executives, lawyers, food-service workers, retail clerks, shop keepers, government employes (federal, state, and municipal), and, of course, taxicab and bus drivers, hotel maids, and an army of maintenance workers. Downtown Portland, by day, is a bustling work scene fed, as we have seen, by a geographically varied urban and suburban population. The downtown area is the hub of this many-spoked residential wheel. Although many changes have occurred since Mr. Pettygrove named Portland after that well-known flip of a coin (Maddux 1952:16), one can still say about this city, that no matter what the weather, or the time of day, restaurants will always be open in Portland.

The Informants: Four Profiles of Waitpeople

Below is background information on my four informants. Because of legal restrictions, the names I use to identify these informants are fictitious and I have slightly altered the ages.

In 1987, while working as a counter clerk in a bakery-deli, I made friends with a co-worker, Marsha, who had been a waitress for 20 years. During one of our discussions, I told her about a book I had just finished reading, The Cocktail Waitress. Interested, she borrowed it from me and read it. Afterward, we talked extensively about it. Marsha said that some parts of the book were accurate, but also called the waitress-bartender interactions "a bunch of shit." When I asked her why, she said: "No real waitress would put up with that crap from a bartender these days." I wondered if the work's ethnographic present might be the problem, and asked her if it was just the time frame, if the waitressing scene might be 
significantly different in the 1990's from how it had been in the 1970's. She responded that it was more likely that the "girls" had never "cocktailed" before working at Brady's, and didn't know how to "put the bartenders in their places." She was firm in her opinion that inexperience, not transferral of women's roles from the home to the bar work environment, influenced the perceptions the "Brady's Girls" had of their "place" in the bar hierarchy.

Out of these discussions with Marsha came the desire, on my part, to focus on a "cultural scene" that would include career waitresses and waiters. Marsha became my first informant. Marsha, in her late 30's, lives with her boyfriend of three years and her nine-year-old son. She has never been married, although she and "Fred" may marry two years from now, if she is convinced their relationship warrants such a commitment. Marsha is a high school graduate, and briefly "gave college a try". She decided it was not what she wanted. All of her work experience has been in waitressing, and she has worked every type of waitressing job, from "cocktailing" to waiting tables in expensive restaurants. She has done waitress work since the age of sixteen, and might like to do something else someday. Right now she doesn't know what that might be, and she is happy with her job.

She works in a small bakery/deli where she is the only waitperson "on the floor" (which means waiting on people who sit at the few available tables), while all other customer service is dispensed from the deli counter, which mainly involves customers who purchase their orders "to go". The waitperson who 
preceded her in this position was a man, and she sometimes laments to the counter help that he received bigger tips than she does because of his gender. Marsha likes her work, however, and hopes to remain at this establishment for several years.

She has developed a very special level of rapport with most of the regular customers, and a few are very special to her. She calls them by pet names, or refers to them as her "kids" or her "family". When one of them was in an accident and had to be hospitalized, Marsha took up a collection from other regulars and from her co-workers, bought flowers and a card, and took them to the individual in the hospital.

Marsha often arrives over an hour before she has.to report for work, and helps the cook by preparing vegetables, slicing and wrapping meat, etc. She is not paid for any of this work, but says she might as well "help out", since she is already there and the work isn't going away. She keeps her station very clean and wellstocked. It's a source of pride for her that the owners never have to remind her to clean up after herself. She's always willing to help other staff, especially the counter clerks and the cook, when she isn't waiting on customers. For Marsha, her customers come first, but she feels, and contributes to, an atmosphere of kinship with everyone in the deli. She likes working the early day shift, since she has a little time for herself before going home in time to be there when her son arrives from school. Her life is well-ordered, and she enjoys what she does. If she 
ever takes on different work, she wants her work life to balance with her private life, the way this job does.

Tad is 28 , has been a waiter for about ten years, and wants to get a music degree someday. He is confident about his skill as a waiter to the point that some of the counter clerks think he is arrogant. Like Marsha, his customers come first. Unlike her, he expects everyone else to drop what they are doing in order that his customers get their wishes. He is not well-liked by the women who work at the counter, and several of them make a habit of ignoring his commands, to the extent that he has "gone around" with some of them about "their attitudes". When Tad comes in to work, he expects his station to have been cleaned by the closing crew the night before. He has a reputation for letting them know his displeasure if the cleaning has not been done. However, he does keep his area clean when he is present, and does not like other employees to come into his station, even though it is the only way to get from behind the counter to the front door without going out the back door and around from the street. He doesn't apologize for his tantrums. He says they work, and he gets his way. He doesn't express a need to be popular with the rest of the staff. He doesn't like his area "invaded" when he is on duty, although he refuses to take his bus trays to the dish washer, claiming it is not his responsibility.

Despite his treatment of other staff, he is talented at giving service, and enjoys the remunerative benefit of receiving higher tips than any of the other employees. He claims to like his work, and does it in a manner he calls 
"professional". When Tad is waiting on a customer, he seems to be performing, although the quality of his service, and his interest in the customer is vastly influenced by how large a tip the customer is "good for". He has often told other employees that he works "for" the tip, not the customer, but gives such good service that the customer would be ashamed not to leave him a good tip. He is pleasant and friendly toward most customers, but has created no bonds with them, with one exception. His interest in most of his customers ends when they have paid their bill, left his tip for him and walked out of the restaurant. The exception is a musician friend, a middle-aged woman, Jeannie, who is allowed to tease him without mercy, and to say things to him he would call harassment if anyone else did it.

Tad recently left the place he had been working for almost three years to take a semi-management position at a restaurant where he would be guaranteed higher tips, and possibly other benefits. A few customers missed his service, but a lot of others have told the new waitperson that they did not miss his attitude. Tad expects to remain at this new position until he can save enough money to go back to school.

Outside of work, Tad is very personable. He considers the "cold professional" image to be a part of the job, but doesn't feel he has to take it with him when he leaves work. When he goes to a restaurant as a customer, he always leaves a substantial tip for those who wait on him. He plays by very specific rules 
in the restaurant business, and if his co-workers find him difficult to work with, they also find him consistent.

Oh Miss is forty years old, but could pass for mid-twenties. She has been a waitress for twenty years, and has worked in a variety of restaurants. A substantial amount of her work has been done in truck stops, and right now she works in a restaurant attached to another business. She says she enjoys her work most of the time, and her primary bonding as a waitress is with the customers more than with other staff. Depending on the atmosphere, she is more than willing to cooperate with the other waitresses, but is not wedded to the idea that she must be accepted by them. She is currently going to night school, and hopes to work in some form of communications when she graduates. She has a sense of loyalty to her customers, and is very nurturing toward them, especially in the case of one group that has been coming in to this restaurant daily for many years. She keeps several telephone numbers of certain customers who are in frail health. If she doesn't see them in a reasonable period of time, she calls to check on them, and relays messages to their friends at the restaurant when they heed help. She knows all of her regulars by name, and frequently the names of their spouses and children, as well. She can give brief biographies of each, what they do, or have done, whether or not they are retired, where they have been, and what their interests in life are.

Oh Miss says that waitress work can be a comfortable trap for her because she finds it easy enough that she could continue doing the work indefinitely. She 
hasn't attempted to pursue a more complex career before now because "waitressing makes it easy for me to be unmotivated to improve myself." After she was divorced, she decided to go to college. She finds nothing demeaning about being a waitress, and would not hesitate to use her skills in this area to support herself at any time, even after she receives a university degree.

Jerry is twenty-five years old. He has worked as a waiter since graduating from high school at seventeen. He wants to have his own business someday, and it might involve food service, but may also be related to music. He sees getting further education as something that might be necessary, but not anything he looks forward to doing. He enjoys his job and most of the people who are his customers. He likes to "make their day", especially if that day hasn't been very good for them until they arrived at his counter. He is warm and personable, and creates an atmosphere of cheerful supportiveness, which appeals to his many regular customers. Some of them make it a point to communicate with him daily, and he considers them important to his work community as well.

There is an unwritten law where Jerry works that employees may not fraternize with customers outside of the workplace. Jerry agrees with that law even though he is very close to several customers while on the job. He keeps no telephone numbers, and, while he would acknowledge a customer outside his workplace, or even perform such favors as giving them change for the parking meter, he keeps his personal life very separate from his life at work. He sees 
himself as being involved in two separate "communities", one at work, and one outside work.

At work, Jerry, like Marsha and Oh Miss, remembers his customers, especially the regulars, by name, and often knows some biographical information about them. He remembers what they usually order, and frequently starts to prepare it for them when he sees them come in the door. He has mastered the art of reading another person's mood, and is skillful at turning a customer's sour attitude into a pleasant one.

Although I have informally chatted with a larger number of waiters and waitresses, the four people profiled above have been most vital to me in this research process. I have done my best to translate their words and ideas about the environment in which they work, and their interactions in that workplace in a way that tells their stories as close as possible to the ways they would tell those stories to the reader.

\section{The Daily Grind}

Workdays for a daytime waitperson in downtown Portland frequently begin between 5:30 and 6:00 a.m. Doors to several eating establishments open at 7:00 a.m. to catch the early coffee and breakfast customer. Frequently fighting the last vestiges of sleep, the waiter or waitress checks in, dons whatever serving costume is required in his/her place of employment, and goes out "on the floor", behind the counter, or where his/her station is. 
The first work responsibilities for the waitperson "on the floor" involve preopening set-up. Flatware, napkins and cups have to be correctly placed on tables or along service counters. Salt, pepper and sugar containers should have been filled by the last employees on the night shift, but these items have to be checked and, if put away at night, returned to each service area for customer use. Additional condiment items have to be prepared and kept in waiting at the waitperson's station. The station might also include other important items, such as bus carts and trays, hot plates, or urns for coffee and hot water, ice receptacles, clean cups, glasses and flatware, and containers of butter, jam, honey, syrup, etc. Sometimes iced tea and soft drink dispensers are in this area, as are espresso machines. The counter person has to fill the deli case with whatever food items the establishment sells. Whether the waitperson is on the floor or behind the counter, he/she has to know the prices of everything, how big a serving to give the customer, and, sometimes, what kinds of ingredients are in the food item.

Whatever the waitperson most needs to enhance customer service must be readily available in her/his work station.

After the waitress or waiter has everything ready for opening, he/she might sit down for a few moments, drink coffee or tea, chat with co-workers, or read. This break is usually not management-scheduled, but is looked on by the waitpeople as a "breather"--a pause to relax and rest before the doors open and the customer onslaught begins. 
Opening happens between 6:00 and 7:00 a.m., unless the restaurant is a "dinner only" or "24-hour" establishment. Usually, there is a small coterie of customers waiting at the door, and waitpeople begin moving at fairly high speed as soon as the doors have been unlocked. A few customers order breakfast at this time and eat it on the scene. Some only order coffee. Coffee customers come in two varieties, those who drink their coffee in-house, and those who get their order "to go". The coffee trade is at high volume from about 7:00 to 7:45 a.m., and again from about 8:00 to 8:45 a.m., reflecting the 8:00 a.m. and 9:00 a.m. start-up times for most downtown workers.

Just before 9:00 a.m., the rate of customer patronage suddenly drops. Waitpeople move a little slower, clear tables that are still covered, replenish coffee and hot water in the urns, and re-stock whatever is in short supply. Morning campers dribble in a few at a time: retired people, maintenance workers with time to fill, managers of downtown residential buildings, and other leisure-time customers. The pace is slower, and waitpeople frequently have time for longer interactions with these customers than they had during the coffee "rushes". These later customers frequently come in every day of the work week, and, as Marsha says: "You can set your watch by some of them."

From 10:00 a.m. on, morning coffee break takes place. The pace quickens somewhat, but customers, especially the regular ones, are usually more relaxed than the pre-work crowd. Coffee-break time scatters customer volume in fifteento-twenty minute increments from about 10:00 a.m. to 11:30 a.m. The turn-over is 
fairly high, but customers and waitpeople take time to visit, joke and tease one another. Most interactions are light and informal, and the communication atmosphere has a nurturing quality.

Lunch-time "hits" like a cattle stampede. Some of the morning customers, especially early coffee customers, come in for lunch, but there are also many unfamiliar faces. The lunch "hour" runs from approximately 11:30 a.m. to 1:30 p.m. Waitpeople are "on the run" through the first part of lunch, reaching a peak ("hitting my stride", as Oh Miss calls it) about 12:30 to 12:45 p.m., and winding down from 1:00 to 1:30 p.m. This is the most stressful part of the waitperson's workday, but it is also the best time for daytime tipping. Most customer/waitperson interaction at this time is strictly business. There is little time for "chit-chat", and the volume of orders to be taken and filled to be served, keeps the waitperson busy.

The lunch rush begins to diminish about 1:20 p.m., and is rapidly declining by 1:30 p.m. A few holdovers last until 2:00 p.m., overlapping with the beginning of the afternoon coffee break, which brings in a much smaller clientele from the business community, but features a marked increase in both high school and college students. Shoppers are in at any time during the day. By 2:00 p.m., the pace has slowed again, and the more leisurely atmosphere returns. Waitpeople whose work shifts will finish between 3:00 and 4:00 p.m. (although some will work until 6:00 p.m.) put lunch-specific items away, refill salt, pepper, sugar and napkin 
containers (called "doing side work"), and again have time to visit with the afternoon regulars, who have stopped in for coffee, tea, or snacks--and visiting.

Once their shift ends, some off-duty waitpeople take time to sit down and talk with the regulars before they leave. Others go to different eating establishments to "hang out" for their after-work break, and become, themselves, part of somebody's crowd of regulars. The daytime scene winds down, and the 5:00 p.m. "rush hour" sees a steady retreat of workers, shoppers and/or students away from the downtown core. Some of the food-service establishments close down at 6:00 p.m., while others prepare to switch over to the evening shift, but that's a different scene.

I derived this basic schedule from information given me by the informants, reinforced by my own observations. I ran it past my informants, and all of them were in agreement as to its basic structure. Although none of them currently work until 6:00 p.m., they agreed that the daytime/nighttime split happens at that time. Within this daytime pattern, many types of interactions occur, reflective of the customer variety and volume each waitperson experiences. Some regulars might stay around until 6:00 p.m., but usually the two hours between 4:00 and 6:00 p.m. are "dead time", neither day nor night. Some restaurants have a non-service period during this time because the customer volume is frequently small.

\section{Customers and Categories in the Waitperson's Eyes}

In the same way that other people develop methods for identifying people with whom they regularly interact, waitresses and waiters have identifiers that help 
them remember who is who, and that help them differentiate between occasional customers, regulars and what Spradley \& Mann (1975) call "real regulars". Some identifiers are related to personal characteristics or the customer's name, or a combination of both; others are related to the reason the customer is in the downtown area, what I call her/his function in the locale. Initially, these identifiers merely help the waitperson remember a customer as an individual. Later, the same nickname, or one derived from it, may become an important part of the waitperson's total mental image of that customer if he or she becomes a part of the restaurant/deli "respite community" where the waitperson is employed. An additional feature of these identifiers is that they often provide an indication of whether or not the waitperson will develop a greater level of intimacy with the customer. Below are categories and identifiers used by waitpersons on the day shift in some downtown Portland food-service establishments (the category names are mine.):

Nicknames based on personal characteristics. From the inclusion of a customer's first name into an identifying label, to the clothing worn or automobile driven by the customer, nicknames for various customers are devised by waitpeople. These nicknames, according to my four informants, frequently help waitpeople remember a customer until/unless first-name familiarity and a level of comraderie is established. But the waitperson may continue to identify the customer with the nickname long after the customer's name is known to the 
waitperson (e.g, "Mr. Saturday-morning-at-ten-0'clock" eventually becomes "Bill, who comes Saturday mornings at ten", to "Saturday Morning Bill").

Frequently customers never know they have been nicknamed by the waitpeople they see on a regular basis. The naming process exists for the convenience of the waitpeople, alone. Not only does a nickname provide a memory tag, it often provides waitpeople with a means to communicate with one another about the customer, sometimes in the customer's presence. The following are types of nicknames informants have given their clients. Where identification of an individual based on her/his nickname has been possible, I have modified the specific descriptive, but the pattern is the same.

Some customers are nicknamed based on occupation-related criteria, e.g. "Businessman Bob", "Suzie Secretary", "Mary-the-Pro". Other nicknames reflect a consistent behavior or condition identified with a specific customer, e.g. "The Earpuller", "Smelly John", "Mike-the-snitch", "Her Majesty, the Queen" (whose nickname reflects both occupation and behavior, "she" is a transvestite). Clothing idiosyncracies sometimes provide a basis for nicknames of customers, especially if the behavior and attire reflect one another in some way. Examples of these are "the witch-ladies", a group of young women who wear black, dye their scraggly hair black, and wear white make-up and dark red lipstick. To provide counterbalance to "the witch-ladies" we have "the Nordstrom girls", young, white, well-dressed, carefully made-up women who pose ("like mannequins", Tad says) while giving the waitpeople their orders (Nordstrom is a fairly expensive department store in 
Portland). "Suits" or "Three-piece-suits" are actually people, usually businessmen and businesswomen who are not only so-dressed, but who usually have overbearing attitudes or who act condescendingly toward the waitpeople.

Nicknaming is an important process for waitperson/customer interaction because it distinguishes an individual customer from the mass of nameless and almost faceless customers. A name, however uncomplimentary or distant it may sound in the beginning, means the customer has appeared in the waitperson's presence often enough to be recognized. The "person off the street" is one step closer to being a "regular" (Spradley \& Mann 1975). Whether or not he or she will develop a close-enough relationship with the waitperson to become a "real regular" depends on the future interactions between the two. A "Suit" who regularly patronizes an establishment may actually become a recognized regular customer while remaining a "Suit". The costume, however, is not the determining factor in the search for the alliances that result in the creation of community. It's the attitude that keeps a person a "Suit" or a "Nordstrom girl", not his Brooks Brothers Executive or her Liz Claiborne original.

Functional. Another method by which waitpeople categorize customers is based on why the customer is in the downtown area. "Workers", for example, are people who fulfill work-related service functions in the downtown core, e.g., secretaries, store clerks, waitpeople, maids, janitors, etc. These customers are different from "professionals": e.g. lawyers, doctors, businessmen. 
There are "shoppers", who are regulars if they come downtown very often, but frequently are unknown to the waitpeople, who just serve them and forget them. The "artistes" (called "hippies" by one informant and "the artsy-fartsies" by another) are members of the city's artistic community. Many of them are associated with the art school, while others are older artists and writers who have their favorite congregating places. "Transients" (bums and very low-income people, mainly men) and "streeties" (young people who are "on the street", frequently homeless, runaways, or a few who have homes but avoid them, preferring to live a lifestyle of rebellion against the atmosphere of their homes) are not usually popular with most restaurant managements. More affluent customers tend to avoid restaurants where "transients" and "streeties" regularly congregate, so they are not seen as an asset to the restaurant's atmosphere.

My informants named a "regular" category to indicate people who patronize the food-service establishment on a regular basis. Some "regulars" become a part of the in-group, others just patronize the place, but never become close to anyone.

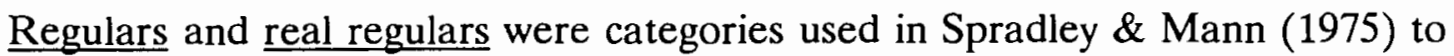
classify two types of customers who patronized Brady's Bar. In the next section we will take a closer look at this classification Spradley \& Mann called real regulars, and apply it to the daytime restaurant scene in Portland.

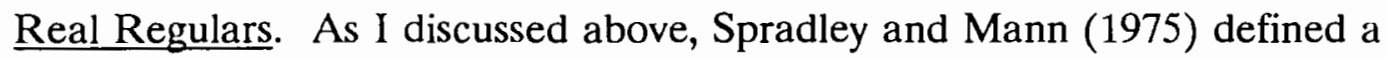
group of customer types who were significant to the cultural scene of "Brady's Bar" because they had become members of the "Brady's Family". There are also 
groups of customers in my data that fit into this real regular designation. Real regulars are described by Spradley \& Mann (1975: 76-77) as follows:

No customer enters the social life at Brady's Bar as a real regular. It is a position that develops over time usually through friendship with the bartenders, occasionally as the regular boyfriend of the waitress. Whatever the link, only men have access to this high status position. Real regulars arrive early and stay late; they seldom miss more than one or two nights each week. Seated around the horseshoe end of the bar, they will swap stories, tell jokes, laugh with the bartender, and inquire about other real regulars who are absent. They all know the waitresses by name and in many respects act toward them like the bartenders do. Of all the customers, real regulars are the most important to waitresses.

There are some differences between the bar scene described above and the restaurant scene. A bar has a bartender as the central figure, while, in a restaurant, waitresses and waiters may or may not have one waitperson in authority. Unlike the bar, customers don't necessarily know who that person is, or, when they do, as in the case of a restaurant having a maitre d'hotel, he is not the focus of customer socializing. Even in cases in which the owner of the restaurant works in a staff capacity, customers are not necessarily inclined to visit with her/him any more often than they do with other waitpeople, according to my informants and my personal observations. In addition, not all the regular customers in my cultural scene form groups (which I call "families" below). Of the groups which are evident, not all primarily have male members with "auxiliary memberships" for those who are female spouses, friends or girl friends of the "regular" members. Others are all female or mixed gender in composition. The 
difference between female "auxiliary" members and female members of a mixed gender group is indicated by a marked atmosphere of egalitarianism in the latter.

These exceptions having been noted, I list below the general characteristics of real regulars following Spradley \& Mann (1975) with modifications from my data to fit the restaurant scene. $\underline{\text { Real regulars: }}$

1. Acquire this status in the restaurant over time, (usually through friendship with the waitpeople).

2. Spend significant and predictable periods of time in the establishment, and are seldom absent more than one or two days of the week.

3. Have a special place (table, booth, coffee bar, etc.) where they congregate.

4. Swap stories, tell jokes, visit with and laugh with one another, (including the waitpeople), and inquire about other members of the group who happen to be absent.

5. Know all waitpeople by name, and frequently interact with them as if they, too, are employed on the staff of the restaurant.

6. Of all the customers, real regulars are the most important to the waitperson.

Although regular customers who are not the equivalent of "real regulars" may share some of the characteristics listed above, a real regular is someone to whom all or most of the characteristics apply all or most of the time. For instance, a group of "streeties" may have a special place to congregate, spending 
significant and predictable periods of time in some establishment, and some might even know all the waitpeople by name. However, they are frequently not friends of the waitpeople, the only swapping that goes on is probably of insults, and their disruptive presence is something the waitpeople can do without, especially if it involves a pack of "streeties". In the Portland restaurant scene, there are three types of groups that sometimes meet the above criteria. I call these the residentials, the campers, and the families. ${ }^{2,3}$

Residentials are people whose permanent housing is in the downtown area. This category doesn't include "transients", whose residence patterns tend to be temporary. Residentials have permanent homes in the area, usually in the many apartment buildings that populate the fringes of the downtown core area. Many residentials are elderly people; others are university, art school and business college students. "Artistes" (especially those involved in the performing arts) are often residentials, as are people who simply like to live close to the bustle of downtown. These customers are known to the waitperson, and do acquire status, especially because of their longevity in the neighborhood. They are frequent customers, and exchange jokes, teasing and engage in acts of levity with the waitpeople and other familiar customers. They usually have favorite tables or places at the counter where they like to sit, and they are familiar with the waitpeople and usually know their names and something about them. Residentials, whether or not they are part of the family in a restaurant, are important to the waitperson because they are usually familiar, predictable 
individuals who could be depended upon in an emergency, and who bring a sense of continuity based on the length of time they have lived in the downtown core.

Campers are people who "hang out". They come in for a cup of coffee, and refill it ten times, especially if it is free. They don't usually purchase very much, but as long as they keep buying something, don't take up space during a "rush" period, and aren't perceived as causing any problems, most restaurant workers and management personnel let them stay. Campers get to know the wait staff, the cook and the other campers. They become fixtures in a restaurant or coffee shop. Some campers, if they meld into an on-going group in the eating establishment, may develop into a family group, or they may have connections with the waitpeople, but not interact with other campers. They definitely spend significant and often predictable periods of time in the establishment, and many have a particular table, booth or other place where they prefer to "hang out". Sometimes they visit with the waitpeople and other customers, but often they prefer to remain separate and private. They usually know the waitpeople by name and interact with them, gaining a certain amount of status purely from the fact that they are present so often, and for considerable periods of time. However, those interactions are frequently dyadic, not as part of a group. Even though they become acquainted with other campers, they usually don't seek these other people out, but stay largely to themselves.

These identifying categories are not mutually exclusive. College students are notorious campers, but so are elderly residentials and "artistes". Groups of 
"streeties" will try "group camping", but are anxiously watched by management, and are usually ejected at the first sign of what might be problem behavior. "Transients" will also camp, and it may be difficult to persuade them to leave, especially if they are drunk. One informant tends to "let them hang around more often in the winter months", especially if they have familiar faces, are sober, and "don't stink too much", because she feels sorry that they have to be out in the cold weather. Over time, campers are the most likely customers to be the primary source for the last and, for this study, the most significant group of "real regulars", family.

The family is a phenomenon described to me by two informants, and one I have seen during periods of observation. My category name comes partly from the designation of the "Brady's Family" (Spradley \& Mann, 1975), and partly from Marsha's description of her relationship with some of her regular customers. A family is a group of real regulars which has been meeting at a particular restaurant, deli, etc. for a number of years, and who know the staff at the restaurant, and possibly the managers and owners, as well. There may be more than one family in a restaurant, but I have never observed more than one daytime family in the establishments I have visited while gathering data.

Each of the establishments I have visited has at least one family. One is primarily male, and has existed for at least one generation. The female participants have been considered the "women's auxiliary", but the woman in the waitress position is part of the regular family. One establishment has a family that 
is primarily female. A few boyfriends and husbands participate, but their participation is similar to that of the women in the previously-mentioned family. The third, both men and women, consists largely of professional or artiste participants.

There is a sense of loyalty among all the people in each family, with ties that frequently cross race, class and gender lines, as well as breaching other social and cultural differences that might otherwise bar the likelihood of regular communication between these individuals. Members of a family have in common the fact that they have made a particular restaurant/coffee shop/deli in which they congregate the equivalent of a "home base". There is a certain part of the restaurant that they consider theirs, a table or group of tables, part of the counter, or a specific booth. They may come in to the establishment any time of day, but probably have special times when most or all of them congregate. They usually respect the "rush" service period limits, and don't hold onto a service area unless a substantial number of them are purchasing a meal. Their interactions are relaxed, informal, intimate, and they are quick to find out where members may be who are not or have not been present. They discuss each other's lives and problems, and sometimes involve themselves in solutions to those problems. They know everyone who works in the restaurant, and treat the establishment as if it were either their own property or their workplace. Since the waitperson is part of their family, they may offer to help her/him out on occasion, bussing some tables or pouring coffee when the waitperson has more to do than time to do it. 
The waitpeople frequently depend on members of the family for emotional support. I have seen a "member of Marsha's family intervene when a customer subjected her to sexual harrassment. The family person inserted herself between Marsha and the offending customer and told him bluntly: "We don't treat our waitress that way, here, and if you can't keep your hands to yourself, you can be removed!" Oh Miss has relayed similar incidents, and Jerry remembers family members who have come to his defense when a customer was hassling him.

Membership in a family may be limited by gender, age group, political ideology or a specific creative or work-related similarity, e.g. artists, poets, or computer hackers, but individuals who are involved with, or related by blood to a family member, and not having family membership, for whatever reason, are often designated "honorary" or "auxiliary" members. While several of the characteristics of real regulars, and therefore of family, define a relationship with the waitperson with whom they most frequently interact, (and this relationship is especially vibrant in the case of family), there is evidence that a particular waitperson is not necessary to the existence of a particular family. The waitperson may go to a different job, and a new person will be hired to fill the job left behind. Many families are so closely connected with one another that they will continue to meet in the same times and places, and will eventually establish a relationship with the new waitperson. For example, the family at the bakery where Tad had worked, transferred their relationship to the new waitperson, Marsha. Oh Miss is one in a 
long line of waitresses who has presided in her position in a family that has been in existence for over thirty years.

\section{CONCLUSION}

In this chapter, I have provided a description of the cultural scene of the downtown Portland restaurants: their setting, the waitpeople, and the categories waitpeople use to describe customers. One of these categories is of particular importance in this cultural scene, forming ties to the restaurant/cafe, to the waitpeople employed in the restaurant, and, sometimes to each other. The groups formed by these ties I have termed families. It seems probable that the family as a customer type occurs in many eating and drinking establishments. It is this subgroup of "real regulars" that can be analyzed as creating the "respite community". 


\section{NOTES}

1. In an ethnographic study entitled "urban witches", Moody's informants give the impression that all who call themselves "witches", are practitioners of Satanism. In fact there are many pagan practitioners who would refer to themselves as "witches" who are not involved in any way in the veneration of Satan.

2. I am using the term residentials to refer to individuals who live in the downtown area. I selected this label because there was no consistency among the informants as to what to call this group of downtown dwellers. The labels campers and streeties were borrowed from all or some of my informants.

3. Terms designated by quotation marks (" ") mark those given me as descriptives by informants. Terms underlined are either my own or, in the case of regulars and real regulars, come from Spradley and Mann (1975). The terms family/families and campers did come from informants and from Spradley and Mann, in the case of family, but I am using them underlined from this point, because they refer to categories I have created for this thesis. 


\section{CHAPTER IV}

\section{"RESPITE COMMUNITY" IN AN URBAN RESTAURANT SETTING}

The "respite community" in the sense I have been using it, can be seen to be created in the families. In this chapter, I will describe two families from the restaurant cultural scene in detail and then examine them from the perspective of the seven-component model discussed in Chapter II to show how the model applies to these groups. This will be followed by a discussion of factors that affect waitperson/customer interaction, including the gender question, tipping, and the joking relationship and the influence of these factors on the sense of "community".

\section{TWO RESTAURANT FAMILIES}

Ye Olde Restaurant's family is predominantly white and male, middle-aged or older, with several members retired. There are two types of women who are a part of this family. There are "auxiliary" members, most of whom are wives or girlfriends of male members. These women reflect the previous structure of this family which, for most of the years of its existence, was primarily composed of male members. There are now a few women who are regular members in their own right. This is a fairly recent phenomenon in this family, with the waitress 
having traditionally been the only female member who was not an auxiliary member.

Members of the family represent a wide class distribution, ranging from Andy, who was, until recently, a street person, to Chef Jim, who is a retired banking executive (the nickname referring to his favorite hobby). One of the most longstanding members of this family is Carnival Jim, who was in the carney/circus business until he retired. He and Chef Jim are the informal "heads" of this family, although they are not invested with control over the other members; their status comes primarily from longevity within the group.

The family get-togethers happen at least five days a week (during the work week), and some members come in on Saturday as well. Chef Jim jokingly says that they have to meet so regularly because they are holding "meetings to advise the President on vital issues". Oh Miss is known as the "Secretary-designate" who "takes notes" and sends them to the President. However, she is also a "voting member" (they never vote), and as such, can express her own opinions.

Some members of the family meet only at Ye Olde Restaurant, but others have ongoing contacts outside. Chef Jim has helped at least one other member of the family with legal assistance, and several members have provided job referrals, references, and other necessary survival services. Oh Miss checks regularly on absent family members, notifying the rest of the family when an illness or other emergency has occurred. Other waitresses and at least one bus boy are peripherally included in this family, although Oh Miss is the only "Secretary- 
designate". The management is not part of this family, but accepts its existence, and acknowledges the group's predominance at Ye Olde Restaurant.

At the Cat's Paw Bakery, two tables in the corner farthest from the main entrance are the preferred hang-out of the Cat's Paw family. This is a family of men and women which has been meeting there for eight years, with most of them living in the neighborhood. Some of them come in as early as 8:30 a.m. for breakfast, returning after the lunch hour to reconnect. Several of them are also musicians, whose primary work hours are in the evening. A few are retired. The "founder" of the family is Jeannie, an apartment house manager and musician. She is a daily visitor, and has a strong connection with the staff at the Cat's Paw. Terry, Jeannie's off-and-on boyfriend, is another family regular, although his participation is highly dependent on how well he and Jeannie are getting along. She broke up with him for a while, and he didn't come to the Cat's Paw when the rest of the family was there, because, "they give me shit if she gives me shit". Terry is often discussed by the rest of the family, whether or not he is present. They give him suggestions about dealing with the problems they say make it hard for him to hold onto a job. Terry gets angry and stomps out for a few days, but he always comes back because these are the people with whom he shares his closest ties. No one else means as much to him as these people. This really is Terry's family.

Tad is peripheral to this family. He formerly worked at the Cat's Paw, but went to a different job. He looks down on some of the family members, but is 
fond of Jeannie as a friend, and even "takes it" from her when she gets angry at his snooty behavior and tells him to "get an attitude adjustment". Marsha now has Tad's old job, and the customers in the family like her attitude better (something they do not hesitate to tell Tad). She was quickly adopted, and fits well with this family, joking and teasing with them in a way Tad would have thought beneath him.

Job referrals get passed around between members of this family, and some of them help the more down-and-out members with meals, old clothes and occasional access to showers and a place to crash. Sometimes when Marsha is busy "on the floor", Jeannie or other family members will pour coffee for other customers, or help by bussing tables. This is a downtown working class family, in which there is a strong emphasis on helping one another. Their survival is often tied to their cooperation with each other.

"THE RESPITE COMMUNITY" AND "FAMILY"

In this section I will go over each of the seven components of the "respite community" and will demonstrate how it applies to the two families being described.

1. There is an aggregate of people who have in common at least one consistent meeting place where they gather on a regular (frequently daily) basis, and where they become acquaintances, then familiars, then participants in an ongoing group. 
The families of both Ye Olde Restaurant and Coffee Shoppe, and the Cat's Paw Bakery formed as a result of these locations being available to them. Each setting has consistently provided space and time for its family to be able to develop an enduring group identity. At Ye Olde Restaurant, some family members have continued their involvement in it for thirty years; and members of the Cat's Paw family have met at their chosen location over the eight-year period the bakery has been in existence.

2. All members of this on-going group get something from coming together in this location and context that emotionally sustains and nourishes them through their participation in the group. Help has been offered and accepted, and a supportive, friendly atmosphere has developed in both locations. Legal assistance and job references have been made available to members of the family at Ye Olde Restaurant, and members frequently stop to visit other members who are ill or temporarily housebound. Likewise, Cat's Paw family members check on those who are ill, help with job referrals and assist poorer members with clothing, food and emergency shelter. Although the material assistance given by both families are important, more significant in these groups than anything else is the sense of emotional nurturance and unity the members give to and receive from one another.

3. Each member is free, while participating in the group, to maintain her/his individual identity. Unlike "Brady's Bar", in which the male/female roles were rigidly established and enforced, the families in both restaurants are much 
more flexible in the freedom available to their participants. Some hierarchy is evident in Ye Old Restaurant's family, since the women who are partners of the male members are "auxiliary members", but the "membership status" does not control who speaks, when they speak, or how long they speak when a conversation is going on. Since there is no need for anyone to control anyone else, people have the freedom to be exactly who they are. The two non-authoritarian men who are leaders do not really lead, although their seniority gives them a certain level of respect from "younger" members. The waitress, as "Secretary-designate", could be said to be in a subservient role, except that she never does anything in that capacity. She doesn't really take notes, nor does she send them anywhere. So she is not a real secretary to the members of the family. It's all part of the joking component of the relationship. Further, Oh Miss' work role as a waitress $\underline{\text { is }} \underline{\text { not }}$ used as an excuse by members of the family to negate her opinions or to relegate her participation to a less-valued level.

The Cat's Paw family is even more autonomous, and more tolerant. Even the noticeable problem two of its members have with alcoholism will not cause the other members to drive them out of the family as long as their behavior in the group setting is not anti-social and problematic. The leader of this family, also, is given respect and deference, but not in such a way as to create expectations about how each person should function. Individualism is highly encouraged and valued in this egalitarian family. 
4. There is a consistent, though flexible number of regular participants, a constancy of interaction among them, and a lasting element of involvement of the participants with one another(Henry, 1958). The family at Ye Olde Restaurant has twenty to twenty-five members, including three waitresses and one bus boy. However, it has been larger and smaller, fluctuating occasionally, as retirees move away, new members get involved and long-term members are, for one reason or another, absent for a time. The Cat's Paw family is smaller, ten to fifteen members, including a waitress, a former waiter, one counter staff person, and one of the dishwashers (a musician who got this job because he knew a member of the family). Contact of members of both families with one another is daily during the work week, and occasionally on Saturday. The Cat's Paw is closed on Sunday, but Ye Olde Restaurant is open part of the day. The level of involvement is a hard element to evaluate, but from the cooperation that exists among the members of both groups, it appears there is a consistent involvement among the members.

5. Participation in this "respite community" is voluntary, with no coercion toward, or on the part of, any involved individual. The problematic issue here is that waitpeople might be described to be in this group involuntarily because it is a part of their job experience. However, the evidence is against coercion because, even though interaction with members of the family might be obligatory on the part of serving food and drink, there is no requirement to be a part of the family. Also, it can be argued that a waitperson has the option of leaving this place of employment at any time he or she chooses. As for the other family members, 
they, too, have a choice. There are many restaurants, delis, coffee shops and bakeries to choose from in downtown Portland, no one has to come back to these locations if he/she does not choose to do so.

6. Individual members of a group may choose not to interact with other group members outside the specific location, even though participation in the group is important to each of them. Members of the family at Cat's Paw live near each other, although some do not. Some formerly lived nearby, but have moved to other locations. These movements have not prevented them from returning regularly to be with the family. Most of the members of the family at Ye Olde Restaurant do not live near each other. A few have worked together in the vicinity, but it is the common location of the restaurant that created the atmosphere in which they came together and remain together.

7. Certain behaviors are practiced, while others are not, based on the formal or informal consensus of the "respite community". The "rules" that govern group behavior are specific to behavioral understandings known only to the group's members. At the Cat's Paw, members of the group have an understanding that they don't walk in swearing at other members. They don't hassle the waitperson, and, if they can't be civil, they leave when another member of the family tells them to leave. Sexist and racist jokes and anti-gay comments are not tolerated. No one says much more than "Hello" before the first cup of coffee. These are all agreed-upon "rules" of the Cat's Paw Bakery family. They aren't written down, and no one has to swear to abide by them, but they are 
enforced by group pressure and consensus. At Ye Olde Restaurant, they don't tolerate people who make fun of those who are disabled or elderly. It isn't considered civilized. Most of the family "rules" here are a little more implicit than they are at the Cat's Paw. It is assumed people know how to behave like gentlemen and gentlewomen. Behavior is a significant element of family interactions in both families. Since the members come from such varied backgrounds, it is important to the comfort level of both groups that members treat one another with respect and cordiality.

The time limit I had to work in did not give me time to make an extensive observation of the complexities of the rules of interaction by which each group functioned. It is obvious rules exist, however, because there are sanctions when those rules are broken, mainly shunning behavior and temporary banishment from the group if a member's behavior is considered intolerable by other members of the group.

As I have shown, the components I have used to indicate "respite community" can be found in the two scenes described. Evidence for some of the components could probably be enhanced by further research. Having discussed families, I will mention that campers, by themselves, do not comprise a "respite community", but individual campers may create a "respite community" with other people, including other campers. They may have interactions with family members, and certainly with the waitperson, but aren't obligated to observed the family rules, and may not crave the intimacy that is a hallmark of the family 
groups. Likewise, residentials may contribute, somewhat, to the sense of community if they choose to seek it out. They don't necessarily develop a level of intimacy with the other real regulars, and they, also, will probably not feel obligated to abide by the rules of the family for the sake of recognizing the family's authority.

\section{OTHER ELEMENTS OF INTERACTION}

Four further elements will now be discussed in the light of waitperson/customer interaction. Each of them has a bearing on the type of "community" which exists in this type of setting, because all four tend to have an impact on the quality of interactions between waitpeople and customers. The four

are: 1) the gender question; 2) tipping; 3) the joking relationship; and 4) the position of the waitperson in the family.

\section{The Gender Question}

Gender can be a significant issue in the potential for close relationships, and thus community, between waitpeople and customers, as well as between members of a family who are customers. No one can honestly say that sexual harassment and gender-based discrimination do not exist in our society. Indeed, they are wellestablished practices and are influenced, in my opinion, by well-entrenched sexism. How this entrenched sexism effects family relationships might be expected to depend on what kinds of authority structures exist in these groups--that is, are they patriarchal in their leadership or do they tend to be egalitarian? As we have seen 
in my descriptions, the two families discussed were fairly egalitarian. A slight tendency to see women in "traditional" roles existed in the family at Ye Olde Restaurant, but it appears to be in transition, with the women's voices being as valid as the men's. In the Cat's Paw family, the leadership is female (one might even call it a benign matriarchy) and not very concerned with reinforcing any roles. There is little question that gender influences how a waitperson is treated by the general public. Sexual harrassment certainly exists between male customers and waitresses. If this research had remained on its initial focus, there would have been greater emphasis on gender problems waitresses experience. However, without a larger sample, I would be stepping into theoretical quicksand to suggest more, given that my research has taken a different direction. This element in waitperson/customer interactions deserves further study.

Nor are waitresses alone in facing harassment, whether sexual or emotional. Waiters, too, are subjected to negative behavior from customers. As far as I could determine, given the data I gathered, these types are not as common in the family structures as they are in general waitperson/customer interactions.

\section{The Significance of Tipping}

Leaving a tip, a sum of money especially for the waitperson, is an established practice of people who eat at a restaurant in our society. The standard rate for a tip is fifteen percent of the total food bill, but the tendency to tip, or to tip the standard rate varies. People usually don't tip at breakfast, and not very much, if anything, for coffee or snacks. Lunchtime tipping is based on 
the restaurant setting, and customer type (e.g., business lunches versus two women shoppers). If the order is for something small, like coffee, toast, a donut, etc., a tip is not usually anticipated, though some people leave more for the tip than the amount of the bill if they appreciate the service given. Those who demand a lot of extra service frequently do not leave tips. These people are referred to as "stiffs" or "deadbeats" (or, in Tad's case, "assholes").

Women are less likely to leave tips than men are, and most women let the man tip if they are accompanied by one -- unless it is a business lunch, in which case both the men and the women tip. Two informants have noticed an increase in women leaving tips. One added that it might have something to do with "women's lib".

Access to larger tips varies depending on the restaurant set-up. Jerry, working behind a counter, splits with other waitpeople what is put in a jar on the counter. Oh Miss, behind a coffee bar, sometimes has to split her tips with a bus boy. Marsha and Tad split their tips with the cook, but Tad, who is male and who "works" the customer for the tips, receives more tip revenue than Marsha, who works equally as hard as Tad. Marsha says this is so because customers traditionally give men larger tips than they give women.

Where family members are involved, the tipping pattern varies from this pattern. When the family is present, there is at least one person who tips for the whole group. (Except, possibly in Jerry's case: since Jerry's tips come from a counter jar, there is no way of always being certain who left a tip.) Again, a larger 
informant sample would be necessary to make a more conclusive statement. However, three of the four informants said being tipped by members of the family is less important to them than being tipped by other customers. The existence of a state of "respite community" between a waitperson and her/his regular customer apparently decreases the expectation on the part of the waitperson that a family member should tip her/him, although it also seems to increase the sense of obligation within one "respite community" (the Cat's Paw) that a tip is provided. I did not, unfortunately, find out how all the customer family members feel about whether or not they should tip the waitperson who is one of them in the family.

\section{The Joking Relationship}

The atmosphere of my cultural scene tends to encourage joking among the participants largely because an informal setting lends itself to levity. According to the literature on the joking relationship in work settings (Bradney 1957; Pilcher 1972; Spradley \& Mann 1975), joking is frequently a means of confronting power imbalances (i.e. employer-employee, difference in employee rank, seniority, customer-service worker). Thus the unequal power dynamics between cocktail waitresses and bartenders frequently lead to joking behavior as a means for the "girls" to release stress (Spradley \& Mann 1975), which is also cited as a purpose for joking among longshoremen (Pilcher 1972). In both of the above ethnographies, sexual innuendo and profanity are significant. These are not necessarily part of joking in the restaurant scene as I observed it, nor as informants described it. Despite the mixed group at Ye Olde Restaurant and 
therefore the potential for tension and discomfort, joking, as it appears in Ye Olde Restaurant's family, is the kind of kidding one hears between siblings at the dinner table. It is usually devoid of profanity, and if there are any sexual references, they are highly veiled.

Cat's Paw people joke continually, and there is occasionally some sexual innuendo, but it is carefully not directed at the waitperson. Terry comes in for a lot of teasing, and has been the butt of a lot of this family's joking. He seems to set himself up for it, and may ultimately get mileage from being the joker of the family. Tad, likewise, has come in for a share of teasing because the group loves to try to get him "off his high horse." Sometimes he endures the play; other times, he loses his temper. The Cat's Paw family appears to use joking as a way of gently notifying a member or staff person that they are out of line.

\section{The Position of the Waitperson in the Family}

The role of the waitperson primarily involved in a family is of particular importance in maintaining the "respite community". Any waitperson who is involved with a family group fills a pivotal position in creating the "respite community", serving as a communication bridge among group members, especially when they don't all appear at the same time, and request information about one another. The waitperson is much like a spider, one who is not part of the web of the family, but who mends and patches it, moving from one part of it to another. However, the unity created by this "respite community" could be perceived to "feed" the waitperson's need for emotional nurturance and support. 
The web of the family is an interactional network, strong, yet vulnerable, fragile but repairable. The spider moves among the strands of the web as the waitperson moves, as a spider does, between and among the strands, or members, of a family. This is where the analogy ends, because once the spider is gone, the web eventually falls apart. In the case of waitpeople leaving a restaurant where there is a family, the new waitperson, if he/she is willing, can be "broken in" to fulfill the previous "spider's" role. Oh Miss has described such an experience to me. The "web" she maintains has existed for approximately thirty years.

\section{CONCLUSION}

In this chapter I have shown how "respite community" is created in the Portland restaurant scene in the sub-group of real regulars called the family. This sense of community affects attitudes toward gender issues, tipping, joking relationships and the role of the waitperson in the restaurant family. Although the data here is relatively small, I would argue for the existance of the "respite community" as a feature of the urban restaurant scene in general, and urge that further research be done in this area. 


\section{CHAPTER V}

\section{CONCLUSION}

Foundations formed in the context of consistent and extended waitperson/regular customer interaction provide a matrix through which the human need to belong may bring people together into an enduring, bonded unity that I have called the "respite community". Although the word "community" is traditionally associated with a geographical location with separate buildings and some type of formal organization, the sense of community does not require such elements. It is not necessary for people to live near each other, have ethnic roots in common, nor to come from the same race or class in order for a "community" type of bonding to occur among them.

Observation in three food-service establishments in Portland, Oregon and interviews with four informants -- two waitresses and two waiters -- have provided preliminary evidence that the "respite community" can exist in such small segments ("cultural scenes") of the urban environment. What once was based only on ethnic kinship, residential proximity and ideological unity, and enforced by rigid rules about appropriate and inappropriate interactions, can be seen to exist much more informally among individuals whose initial bonding may have resulted from 
drinking coffee in the same establishment during the same time of day over a period of months or years.

Groups here designated as families can exist in rural as well as urban settings, but their significance to their urban participants is greater because of the need for intimacy and group unity within the urban setting.

I do not suggest that the "respite community" can replace other, more formal concepts of "community", only that perceptions of "community" be broadened to include the many possibilities that can exist in a world of complex social organization. The model proposed in this paper through the seven suggested components, offers my contribution to the search to discover what constitutes "community". 


\section{REFERENCES}

Anonymous 1991. The Portland Downtowner. June 24: 13-15.

Boas, Franz 1927. Primitive Art. New York: Dover.

Bradney, Pamela 1957. The Joking Relationship in Industry. Human Relations 10: 179-287.

Cole, Donald Powell 1975. Nomad of the Nomads. Arlington Hts., Illinois: AHM Publishing Corp.

Daly, Mary 1978. Gynecology: The Metaethics of Radical Feminism. Boston: Beacon Press.

Donovan, Frances 1920. The Woman Who Waits. Boston: The Gorham Press.

Doyle, Jean 1972. "Helpers, Officers, and Lunchers: Ethnography of a Third Grade Class"; in Spradley \& McCurdy, 1972. The Cultural Experience: Ethnography in a Complex Society. Palo Alto: Science Research Assoc.

Eames, Edwin and Judith Granich Goode 1980. "Public Places"; in Press \& Smith, Urban Place \& Process: Readings in the Anthropology of Cities.

New York: Macmillan.

Foster, George M. 1962. Traditional Cultures and the Impact of Technological Change. New York: Harper \& Row.

1967. Introduction: What is a Peasant; in Potter, Diaz \& Foster, 1967. Peasant Society: a Reader. Boston: Little, Brown \& Co.

Fox, Mary Frank \& Sharlene Hesse-Biber 1984. Women at Work. Palo Alto: Mayfield Publishing Co.

Frysztacki, Krzysztof 1983. "Microsocial Components of Urban Structure: on the Example of Cracow"; Urban Anthropology: 12:263-278.

Handlin, Oscar 1951. The Uprooted. Boston: Little, Brown \& Co. 
Hazan, Haim 1984. "Temporal Conceptions of Community in a Sponsored Urban Setting". Urban Anthropology 13:33-64.

Henry, Jules 1955. Culture Against Man. New York: Random House.

1958. "The Personal Community and its Invariant Properties"; American Anthropologist 60:827-831.

Honigmann, John J. 1976. The Development of Anthropological Ideas.

Homerwood, Illinois: The Dorsey Press.

Keefe, Susan Emley 1980. "Personal Communities in the City: Support Networks Among Mexican-Americans and Anglo-Americans"; Urban Anthropology 9:51-74.

Keesing, Robert M. \& Felix M. Keesing 1971. New Perspectives in Anthropology. New York: Holt, Rinehart \& Winston.

Keiser, Lincoln 1969. The Vicelords: Warriors of the Sreets. New York: Holt, Rinehart \& Winston.

Kollias, Karen 1965. "Class Realities: Creating a new power base"; Quest 1:28-43.

Langness, L. L. 1965. Life History in Anthropology. New York: Holt, Rinehart \& Winston.

Lewis, Oscar 1951. Life in a Mexican Village: Tepotzlan Restudied. Urbana, Illinois: The University of Illinois Press.

1961. The Children of Sanchez. New York: Random House.

1966. La Vida. New York: Random House.

Liebow, Eliot 1967. Tally's Corner. Boston: Little, Brown \& Co.

Lowie, Robert 1925. Primitive Religion. London: George Routledge \& Sons.

Lynd, Robert \& Helen Lynd 1929. Middletown. New York: Harcourt, Brace \& Co.

1937. Middletown in Transition. New York: Harcourt, Brace \& Co.

Maddux, Percy 1952. City on the Willamette: the Story of Portland, Oregon.

Portland: Binford \& Morts. 
Mann, Brenda J. 1972. "A Little Gem: The Ethnography of an Urban Jewelry Store"; in Spradley \& McCurdy, 1972. The Cultural Experience:

Ethnography in a Complex Society. Palo Alto: Science Research Associates.

1976. "The Ethics of Field Work in an Urban Bar"; in Rynkerwich \& Spradley, 1976. Ethics and Anthropology: Dilemmas in Fieldwork. New York: Wiley.

Mars, Gerald \& Michael Nicod 1984. The World of Waiters. Boston: G. Allen \& Unwin.

Mead, Margaret 1928. Coming of Age in Samoa. New York: Doubleday.

Messenger, John C. 1969. Inis Beag: Isle of Ireland. New York: Holt, Rinehart \& Winston.

Meyerhoff, Barbara G. 197.8. Number Our Days. New York: E.P. Dutton.

Moody, Edward J. 1971. "Urban Witches"; in Spradley \& McCurdy 1971. Conformity and Conflict. Boston: Little, Brown \& Co.

Murdock, George P. 1949. Social Structure. New York: Macmillan.

Partridge, W.L. 1972. The Hippie Ghetto: the Natural History of a Subculture. New York: Holt, Rinehart \& Winston.

Pilcher, William.W. 1972. The Portland Longshoremen: a Dispersed Urban Community. New York: Holt, Rinehart \& Winston.

Potter, J. M., M. N. Diaz \& G. M. Foster 1967. Peasant Society: a Reader. Boston: Little, Brown \& Co.

Press, Irwin \& Estellie Smith 1980a. "Introduction"; in Press \& Smith, Urban Place \& Process: Readings in the Anthropology of Cities.

1980b. Urban Place \& Process: Readings in the Anthropology of Cities. New York: Macmillan.

Redfield, Robert 1930. Tepotzlan: a Mexican Village. Chicago: University of Chicago Press. 1955. The Little Community: Viewpoints for the Study of a Human Whole. Chicago: University of Chicago Press. 
Rubin, Lillian Breslow 1976. Worlds of Pain. Life in the Working Class Family. New York: Basic Books, Inc.

Rynkerwich, Michael A. \& James P. Spradley 1976. Ethics and Anthropology: Dilemmas in Fieldwork. New York: Wiley.

Shepar-Hughes, Nancy 1981. The Irish of South Boston.

Unpublished manuscript.

Siskind, Janet 1973. To Hunt in the Morning. London: Oxford University Press.

Spradley, James P. 1970. You Owe Yourself a Drunk, an Ethnography of Urban Nomads. Boston: Little, Brown \& Co.

1979. The Ethnographic Interview. New York: Holt, Rinehart \& Winston.

Spradley, James P. \& Brenda J. Mann 1975. The Cocktail Waitress: Woman's Work in a Man's World. New York: Wiley \& Sons, Inc.

Spradley, James P. \& David W. McCurdy 1971. Conformity and Conflict. Boston: Little, Brown \& Co.

1972. The Cultural Experience: Ethnography in a Complex Society. Palo Alto: Science Research Associates.

Starhawk 1979. The Spiral Dance: A Rebirth of the Ancient Religion of the Great Goddess. San Francisco: Harper \& Row.

Steinem, Gloria 1977. "Where the Women Workers Are . . the Rise of the Pink Collar Ghetto"; Ms. March:51.

Stolz, Barbara A. 1985. Still Struggling: American's Low-Income Working Women Confronting the 1980's. Lexington, Mass./Toronto: D.C. Heath \& Co.

Stromberg, Ann H. \& Shirley Harkess 1978. Women Working: Theories \& Facts in Perspective. Palo Alto: Mayfield Publishing Co.

Terkel, Studs 1972. Working. New York: Pantheon Books.

Velazquez, Elaine 1990. Story of the Yiu Mien (film). Portland \& Eugene: Oregon Committee for the Humanities. 
Vidich, Arthur J. \& Joseph Bensman 1958. Small Town in Mass Society: Class, Power, and Religion in a Rural Community. Princeton: Princeton University Press.

Warner, W. LLoyd 1949. Democracy in Jonesville. New York: Harper \& Row.

Weitzman, Lenore J. 1979. Sex Role Socialization: a Focus on Women. Palo Alto: Mayfield Publishing Co.

Whyte, William Foote 1943. Street Corner Society. Chicago: University of Chicago Presss.

Woodham-Smith, Cecelia 1965. The Great Hunger. London: Four Square.

Woods, Susan 1979. "Waitressing: Taking Control of Our Work"; Quest 5:82-94.

Wolf, Eric 1959. Sons of the Shaking Earth. Chicago: University of Chicago Press. 1966. Peasants. Englewood Cliffs, N.J.: Prentice-Hall. 
APPENDIX A

GLOSSARY: WAITRESS/WAITER TERMINOLOGY 


\section{WAITPERSON TERMINOLOGY}

This is a partial listing of terms waiters and waitresses used in their interactions with me during interviews conducted with two of each in Portland, Oregon. I call this list partial because there are probably many more occupation-specific terms I have not heard or recorded because of the limitations of time and the small size of my sample. Also, not all of these terms were used by all four of my informants.

Artifact: an item left by the customer at her/his customer's space at the table or counter to let the waitperson know the customer will be returning (e.g., the customer went to the bathroom, to make a telephone call, etc.), so the waitress doesn't clear the customer's dishes away from the space. Typical artifacts: reading glasses, cases for reading glasses, cigarette pack/lighter/case.

Book: the pad of order forms the waitperson uses to write down a customer's order. Each "page" from the book is, in turn, given to the cook, who fixes the customer's order, back to the waitperson, who gives it to the customer in the form of her/his "bill", and to the hostess or the waitress by the customer when the bill for food is paid.

Breather: period of time before opening when the waitperson stops to take a short break, after set-up, before the customers begin arriving.

Bus Boy: (non-gender-specific term: Busser) employee whose job is primarily to clear and wash off tables/service area after the customer leaves. In some establishments, the bus boy also washes dishes. In larger establishments, there is a dishwasher. In some restaurants, the bus boys/bussers restock dishes used "on the floor" and reset the service area (put out silverware, napkin and cup at each place).

Camper: a person who stays at the restaurant for a long time, drinks coffee, or eats or drinks small, inexpensive amounts. Campers frequently don't buy very much food. He or she may read, write, visit with other customers or with the waitpeople, or just people-watch.

Cashier: an employee who takes money for the restaurant in payment for the customer's meal after the customer is finished and preparing to leave the restaurant. Sometimes the cashier is also the hostess. Sometimes the waitperson performs this function.

Closing: 1 . When the doors of the restaurant are closed for the night, or the restaurant is not taking in any new customers, and the employees are encouraging customers who are still in the building to leave. 2 . When the cashier counts all the 
money in the cash register, counts the totals of all the tickets, and (hopefully) reaches a balance.

Cocktailing: the work of a waitress/waiter who works serving drinks in a bar or lounge.

Coffee break: 1. a time-frame in the work day of the waitperson when people come in to the restaurant to get beverages and sometimes a light snack. There are usually two coffee breaks in the service day, mid-morning and mid-afternoon. 2. The waitperson's own break time.

Coffee customer: a regular customer, usually one who comes early in the morning or during the mid-morning coffee breaks, who mainly purchases coffee, and perhaps a pastry, but who rarely buys anything else.

Coming on: hustling/"propositioning" the waitperson; usually done by male customers to waitresses. A behavior that is not, as a rule, appreciated by waitpeople.

Condiments: flavorings for food that are added to the food by the customer after the food has been delivered to the customer. Some condiments are normally kept on the table/counter for the customer's use (e.g., salt, pepper, sugar); others have to be requested from the waitperson or bus boy (e.g., catsup, mustard, hot sauce).

Counter: long, low service area customers sit at, usually having stools on one side; usually for single customers (those who are alone at the restaurant). Customers sit on one side of the counter and the waitperson works on the other.

Cruising: still busy during a rush period, but not rushed or "scrambling" anymore. One waitress calls it "hitting my stride".

Crunch: (or The Crunch) the "first wave" of customers for the lunch "hour" service period.

"86": 1. "out of" something on the menu; e.g., "86" the taco salad means "We don't have any more taco salad." 2. throw someone out of the establishment because he/she is being disruptive, violent or destructive.

Family: regular customers who form an on-going group, come into the establishment regularly during the week, and who are friendly with the staff at the restaurant, especially with the waitpeople.

First wave: initial rush of customers at any regular meal time. 
Fountain: area where soft drinks, milkshakes, etc. are prepared.

Group campers: a recognizable group of customers who come into the restaurant, sit in one special service area on a regular basis and socialize. Group campers frequently don't spend much money, and, if they are teenagers or unconventionallooking, management watches them nervously and ejects them at the first sign of "trouble".

Hostess: woman employee who greets customers, seats them in the restaurant, gives menus to each person in the party, and may also bring ice water, coffee, tea, etc. Not all restaurants have hostesses. In some restaurants the hostess is also the cashier.

In the Service Area: being at one's "station" "on the floor" or behind the counter.

Jerk: someone giving the waitperson a difficult time.

Maitre de: short for Maitre d'Hotel: 1. the person, usually male, who is in charge of the waiting staff at a more formal restaurant. Also called Head Waiter. 2. when used in a derogatory manner, meant to imply that one member of the waiting staff thinks he/she is better than or knows more than the other waitpeople, who don't necessarily agree with that individual's self-evaluation ("Who do you think you are, the maitre de?").

On the floor: working; waiting on customers; function in one's "station" during one's work shift.

Opening: unlocking the doors of the restaurant at the beginning of the service day.

"Order In!": what the waitperson says to the cook to let him/her know an order has been submitted to be prepared for a customer.

Punch in/Punch Out: when the establishment uses a time-clock to record the waitperson's time at work, each employee has a card with her/his name on it, which the employee inserts into a slot in the time-clock to record when the employee's shift status changes. Punch-in happens at the beginning of the work shift and after the waitperson finishes her/his meal break. Punch-out happens at the beginning of the waitperson's meal break and at the end of her/his work shift.

Regular: a customer who comes in often, every work day, or on a regular weekly basis. 
Re-stock: fill necessary service containers to prepare for the opening, the next meal, or before going off shift; replace supplies.

Scrambling: hurrying, a little "off balance", to be waiting on a suddenly-high volume of customers; a little "pushed".

Set-up: prepare or reorganize service area in preparation for the next customer(s). Includes putting silverware, napkins, cups, etc., in place and making sure the service area is cleared, cleaned up and attractive.

Shift: the whole period of time, usually four or eight hours, during which the waitperson is on duty, counting coffee breaks, but excluding the lunch break. During this period, the waitperson is also said to be On shift.

Slip: 1. One of the "tickets" on which the waitperson has taken the orders for her/his customer. At the end of the shift, the totals on all her/his slips are added up, and are used to figure the $8 \%$ tip tax she/he pays on presumed tips received. 2. Pieces of paper given the waitperson each morning, reflecting the abovementioned income information from the previous work shift.

Station: specific area in the restaurant where a specific waitperson has been assigned to work. May be "permanent" or "flexible".

Streeties: young people who live or hang out in the streets, often congregate in the various restaurants for the purpose of group camping, and who are frequently at odds with management because they never spend very much money, but like to take up space in the restaurant.

Ticket: one page from the book. The piece of paper on which the waitperson writes the customer's order.

Tip: money left for the waitperson by the customer. Given over and above the cost of the meal as an expression of appreciation for the waitperson's service (also called a Gratuity or a Toke according to one informant).

Tipping: the act of leaving a tip for the waitperson.

To-Go: an order which will be taken with the customer, not eaten at the restaurant.

Ugly, Ugliness: a co-worker who is behaving like a jerk. (" " is being ugly today." or "There seems to be some ugliness going around this morning.") 
Uniform: specific clothing worn by the waitperson as designated by the employer. Sometimes this clothing is provided by the employers; other times its purchase/ownership is an occupational requirement the employee must meet as a personal out-of-pocket expense.

Wheel: a devise with a rotating band with clips around the outside of it; usually in the window of a cook's station. The waitperson puts her/his tickets on the wheel so the cook will be able to reach the customer's order. 
APPENDIX B

INTERVIEW QUESTIONS 
Interview Question Set I: Career expectations, experiences, goals

\title{
Statistical information
}

\author{
Age: \\ Gender: \\ Marital status: \\ Institutional education level and concentration: \\ Family structure: \\ Career and personal career goals:
}

\section{Preliminary questions}

1. As a child, what did you want to be when you grew up?

2. Did you think you would like to work as a waiter/waitress?

3. Did you think you probably would work as a waiter/waitress?

4. Did someone you know and admired when you were a child work as a waitress or a waiter?

5. Do you expect to remain in this occupation, and if so, what do you see as your future in the restaurant business?

6. If the answer to \#5 is "no", what other occupation(s) do you see yourself pursuing?

7. Is further training required for the other occupation, and, if so, how and when do you expect to acquire this training?

8. How do you respond to people calling waiting an "unskilled" or "semi-skilled" occupation?

9. Did you receive any formal training in waiting tables, either before you started this work, or at any time afterward? What training have you received, when and where?

10. What, in your opinion, is the most effective way to learn to be a waitperson? What skills are the most important to have in this work?

11. How did you "learn the ropes"? 
12. Do you/would you want your child, younger sibling, etc., to be a waitperson?

13. What aspects of your work do you find the most satisfying? The least satisfying? How satisfying is the work you do?

14. Do you believe that waiting tables is largely a "woman's occupation? Why or why not?

15. How do you feel about the stereotyping of waiting as being "women's work"?

16. What do you think "women's work" is, if such a kind of work exists?

17. How do you feel about waiting on people? On men? On women? On children of either sex? (including teenagers) On couples or groups? On different types of people (race, class, sexual preference)? Please elaborate.

18. What do you see as the differences between women as waitresses and men as waiters?

19. Is gender a factor in how the person waiting tables is treated by customers, co-workers, etc. (e.g., tipping practices, perceptions of the waitperson as a person, a professional, worthy of respect)? Do women customers treat waitresses and waiters in a different manner? Do male customers treat waitresses and waiters in a different manner?

20. Is waiting a job, a profession, or an occupation? Why?

21. How do you feel about the practice of tipping? Do you think your opinion of tipping differs from the attitudes your customers have about the practice? In what way(s)?

22. What physical impact(s) does waiting have on you personally? Positive and negative effects.

23. Do you want to raise any issues I haven't brought up, or revisit any of the subjects already discussed? 
Interview Questions Set II: The Grand Tour, or

"What is your work day like as a waitperson?"

Before we begin with the second set of questions, are they any additions or corrections you have from the last time we talked -- anything you thought about later that you feel should be added to what you have already told me? This group of questions will be directed toward areas of your work you believe are important or necessary for me to know about in order for me to get a clearer understanding about food service work from your perspective. Please feel free to bring up important information, even if I don't specifically ask for it.

1. Tell me about a typical day on the job. Start from the beginning, with your arrival at work, and tell me what you do from the time you walk in the door until you leave at the end of your shift.

2. Now that we have recorded a typical day, what variations from this schedule are there? For instance, do you have certain tasks that have to be done during holiday seasons only? I'm looking for any differences from the schedule you have given me.

3. Are there any tasks you do that are different from the tasks other waitpeople in your workplace do, or vice versa? What are those tasks, and how are they assigned?

4. Are there tasks that you interchange with other employees? What are those tasks, and why and how do they get passed around?

5. Is there anything you want to add here that you believe belongs with this group of questions? 
Interview Questions Set III: Waitperson/Customer Interactions

This group of questions is directed toward examining interactions between waitresses/waiters and customers from the waitperson's point of view. As before, if you think I have left anything important out that relates to this set or previous sets of questions, don't hesitate to tell me.

1. When a customer comes into the restaurant, when do you notice her/him? When she/he enters the restaurant? Steps into your station? Sits down?

2. What do you do to initiate contact? What is your "rap" to start the process of waiting on the customer? Does this vary with the customer? How so?

3. What are the steps to giving service to a customers?

4. What do you do to wind up the process and end your contact with the customer? Does this vary?

5. If you had to categorize customers into different types, what sorts of categories would you use? How would your service vary with these different types? 
APPENDIX C

INFORMANT HANDOUT 
For Your Information:

I am a graduate student in the Department of Anthropology at Portland State University and am doing research for my Master's thesis. My research involves a study of waitresses, waiters and their interactions with customers. Any information you choose to give me on this subject, in response to the questions will contribute to the data base I will be putting together in order to write the thesis. I will use a code name for you, and any information you give me will be recorded under that name. This way, you are granted anonymity and your identity, place of employment, etc., will be kept confidential for your protection. I will not tell your employer(s) what you say to me, nor give any person information with which they can identify you without your express permission.

The information I am seeking in this study will help me write about the experiences of people who have made careers as waitresses or waiters, the level and types of work they do, and some of the kinds of interactions that happen between waitpeople and customers. I have three sets of questions to ask, and am hoping to find two to four informants with a good enough relationship with their employers that I will be able to arrange, with the cooperation of the informant and the employer, times to observe the informant on the job. If you believe you could offer this opportunity, and you feel safe being observed as you do your work, please let me know.

If you have any questions or concerns about this research project, please ask me, or, if you have concerns you don't feel you can address with me, you are welcome to contact my Thesis Advisor at Portland State University, Dr. Sharon Carstens, (503) 725-3914.

Thank you for your willingness to share your experience and knowledge with me. I will do everything in my power to make our work together a positive and constructive time for both of us. If you want to have access to the written study when it is completed, please let me know. 
APPENDIX D

INFORMED CONSENT FORM 
Please Read \& Sign this Consent Form:

I hereby agree to serve as an informant in the research project on waitresses, waiters and customers, which is being conducted by Patricia L. MacAodha. I understand that the study involves one to three interviews with me, as well as a possible period of observation of my on-the-job performance. I understand that possible risks to me associated with this study are invasion of privacy, inconvenience and demand on my personal time.

It has been explained to me that the purpose of the study is to learn more about the work career waitresses and waiters do, and about their interactions with customers. I may not receive any direct benefit from my participation in this study, but my participation my help to increase knowledge and understanding of my occupation, which my ultimately benefit me and others.

Patricia MacAodha has offered to answer any questions I may have about the study and what is requested of me in the study. I have been assured that all information I give will be collected anonymously, and that my name, identity, place of employment, employer and fellow employees will be kept confidential, and will not be used for publication or public discussion purposes without my express permission.

I understand that I am free to withdraw from participation in this study at any time. I have read and understand the foregoing information, and agree to participate in this study.

Date Signature

If you experience problems that are the result of your participation in this study, please contact Dr. Sharon Carstens, Department of Anthropology, (503) 725-3914, and also the Chair of the Human Subjects Research Review Committee, Office of Grants and Contracts, 303 Cramer Hall, Portland State University, (503) 725-3417. 